\title{
SOLIDARIEDADE ÉTNICA, PODER LOCAL E BANDITISMO: uma quadrilha calabresa no Oeste Paulista, 1895-1898*
}

\section{Karl Monsma, Oswaldo Truzzi e Silvano da Conceição}

Em dezembro de 1895, o major José Ignácio de Camargo Penteado, fazendeiro de São Carlos, recebeu uma carta em língua italiana ameaçando incendiar sua fazenda ou assassiná-lo caso não

* Esta pesquisa recebe o apoio do CNPq e do Programa Brasil Latino da Fundação Cassamarca. Anteriormente, recebeu financiamento da Fapesp. Uma versão anterior foi apresentada no XXVI Encontro Anual da Anpocs, Caxambu, MG, outubro de 2002. Agradecemos os comentários de Elisabete da Costa Leal e de um parecerista anônimo da RBCS. Agradecemos ainda a gentileza e a atenção de diretores e funcionários da Fundação Pró-Memória de São Carlos, do Arquivo do Estado de São Paulo e da Unidade Especial de Informação e Memória da Universidade Federal de São Carlos. Carolina Albuquerque da Silva, Lania Stefanoni Ferreira, Simone Medeiros e Thiago Soares, bolsistas do PIBIC, pesquisaram alguns dos processos discutidos neste artigo.

Artigo recebido em outubro/2002

Aprovado em maio/2003 deixasse trinta contos de réis no pontilhão da estrada de ferro na noite de natal. ${ }^{1}$ O major, que já recebera outra carta do mesmo teor e certamente não queria deixar tal presente de natal para italianos desconhecidos, desconsiderou a carta. $\mathrm{Na}$ noite de 25 de dezembro, o depósito de aguardente e outras instalações da fazenda foram incendiados, resultando em prejuízos de aproximadamente 35 contos de réis. No dia 26, recebeu outra carta dizendo que ele seria assassinado se não depositasse o dinheiro no lugar indicado duas noites depois. Desta vez, o major alertou o delegado de polícia, que foi com a força pública e vários voluntários observar o pontilhão na noite do dia 28. Por volta das seis horas do dia 29 chegou um indivíduo e olhou o pontilhão. Ele foi preso, mas parece que foi solto por falta de provas, porque não foram encontradas mais referências sobre ele no inquérito a respeito do incêndio. 
O incêndio na fazenda de José Ignácio Penteado foi o primeiro evento de uma onda de crimes em São Carlos e municípios vizinhos, que aterrorizou sobretudo as elites e durou mais de dois anos. Os autores pertenciam a uma quadrilha de imigrantes italianos, liderada por Francisco Mangano. Com o fracasso desta e outras tentativas de extorsão, eles passaram a praticar assaltos a pessoas e arrombamentos de casas e lojas, atuando tanto na cidade como na zona rural, mas sobretudo especializando-se em emboscadas nas estradas rurais. Os alvos preferidos dos assaltos eram fazendeiros que traziam grandes quantias de dinheiro da cidade para pagar os colonos e os camaradas. Em março de 1898, quando foram presos, os principais integrantes da quadrilha preparavam assaltos ao Banco União e ao trem de pagamento da Companhia Paulista de Estradas de Ferro.
O Quadro 1 apresenta uma cronologia dos principais crimes mencionados no inquérito e no processo criminal contra o bando. O quadro sugere que a freqüência dos crimes se acelerou até a prisão do bando, embora tal impressão possa resultar de uma ênfase maior nas atividades mais recentes no inquérito e no processo. Ou seja, vários crimes do início do período podem simplesmente não aparecer nas principais fontes disponíveis.

No início de novembro de 1897 , o roubo e a tentativa de latrocínio contra o fazendeiro Joaquim Botelho de Abreu Sampaio sensibilizaram as elites locais, e o delegado em exercício coronel Leopoldo Prado, que também era fazendeiro, não poupou esforços na tentativa de capturar os criminosos. Uma carta anônima denunciou três italianos como autores do crime. O delegado prendeu-os, mas teve de soltá-los por falta de provas.

\section{Quadro 1 \\ Cronologia dos Principais Crimes Envolvendo o Bando Mangano (eventos mencionados no processo)}

- 25 para 26/12/1895 - Incêndio na fazenda de José Ignácio de Camargo Penteado.

- 5/10/1896 - Assalto ao italiano Giacomo Baptisaco, trabalhador de roça (trazendo dinheiro do banco para o fazendeiro João Borges de Oliveira).

- 4/12/1896 - Roubo do cofre do hotel dos italianos Francisco Loriggio e Vicente Callibo.

- 30/1/1897 - Agressão e tentativa de assalto a Florêncio José de Moraes.

- 18/9/1897 - Arrombamento e roubo à casa do espingardeiro italiano Fortunato Baroni.

- 1/11/1897 - Roubo de cavalos de Antonio Salles e Antonio da Cunha.

- 6/11/1897 - Assalto e tentativa de assassinato, com ferimentos graves, do fazendeiro Joaquim Botelho de Abreu Sampaio.

- 1/1898 - Roubo da casa do italiano Paschoal Cachuchelli.

- 1898 - Assalto a um "patrício".

- 1898 - Roubo a Miguel Lebre.

- 2/1898 - Ferimentos com tiros e assalto ao mascate "turco" Salomão Elias.

- 4 ou 5/2/1898 - Roubo e assassinato do fazendeiro português José Joaquim Duarte Moreira.

- 5/2/1898 - Roubo e espancamento do "preto" José Moreira da Silva, roceiro.

- 5/2/1898 - Tentativa de assalto e ferimentos graves (de espingarda) em Porfírio Alvares da Cruz, administrador de fazenda.

- 12/2/1898 - Arrombamento e roubo da casa comercial dos "turcos" Abdo Kfouri e Antônio Kfouri.

- 25/2/1898 - Ferimentos com tiros e tentativa de assalto ao "preto" Marcos Barbosa, maquinista.

- 6/3/1898 - Assalto e espancamento do negociante ambulante português Dionísio Antônio da Silva.

Fonte: Conceição, 2001; Fundação Pró-Memória de São Carlos, Processos Criminais, Caixas 272 e 273, n. 90, 1898, vários réus. 
Ele também prendeu e espancou vários outros italianos, mas acabou não descobrindo nada. ${ }^{2} \mathrm{~A}$ comunidade italiana parecia impenetrável.

Os integrantes da quadrilha provinham de uma região da Itália, a Calábria, bem conhecida pelo banditismo no século XIX, e há indícios de que alguns deles já tivessem experiência com essa atividade antes de emigrar. Apesar de mais de 36\% dos italianos imigrados para o Brasil entre 1878 e 1902 serem meridionais (Trento, 1989, p. 39), e da super-representação de italianos entre os acusados de roubos e arrombamentos na época da imigração em massa (Fausto, 1984), o envolvimento de imigrantes italianos no banditismo ou no crime organizado era raro no Brasil. A quadrilha Mangano, de São Carlos, é o único exemplo que conhecemos, embora o tema seja pouco pesquisado, podendo ter havido outros bandidos italianos no Estado de São Paulo com atuação mais limitada. A raridade do banditismo italiano no Brasil contrasta não somente com a do Sul da Itália, mas também com algumas das grandes cidades dos Estados Unidos, onde uma parte dos imigrantes, especialmente sicilianos, organizou quadrilhas especializadas em extorsão, fenômeno inicialmente conhecido na mídia como a "Mão Negra" (Black Hand). Na década de 1920, com a Lei Seca, algumas dessas quadrilhas adquiriram um papel predominante no tráfico de bebidas alcóolicas e transformaram-se em poderosas redes criminosas, conhecidas coletivamente como Máfia ou "Cosa Nostra" (Anderson, 1965).

Caso excepcional no Brasil, a quadrilha Mangano, que atuou no campo e na cidade de São Carlos, pode nos ajudar a entender por que, de maneira geral, o Estado de São Paulo não fornecia condições propícias nem para o banditismo rural, como o da Itália meridional, nem para quadrilhas urbanas de imigrantes, tal qual presente em algumas cidades norte-americanas. A comparação com a Calábria e com os Estados Unidos, e a história do próprio bando Mangano, apontam a importância decisiva de dois fatores para explicar a raridade do banditismo e do crime organizado entre italianos no Brasil: a falta de elites dispostas a apoiar e proteger esta atividade e as dificuldades para italianos corromperem as autoridades lo- cais, especialmente a polícia. Em São Carlos, onde havia certa concentração de calabreses, entre muitos italianos de outras origens, uma quadrilha de bandidos calabreses atuou com impunidade durante alguns anos em função de uma epidemia devastadora de febre amarela, que afastou grande parte da elite local e debilitou a polícia.

A organização, a trajetória e o desmantelamento da quadrilha Mangano também fornecem evidências sobre as formas e os limites da solidariedade italiana à quadrilha. A solidariedade étnica dos calabreses contribuiu para a coesão interna do bando, que não tinha estrutura formal de liderança, rituais de adesão ou regras internas explícitas, mas não explica o silêncio dos outros italianos. Concluímos que estes não denunciaram a quadrilha principalmente porque desconfiavam das autoridades brasileiras e temiam a vingança do bando. Com a prisão dos bandidos e o evidente fim de sua impunidade, não faltaram italianos dispostos a depor contra eles, e os líderes da comunidade italiana celebraram a queda da quadrilha.

\section{A emigração calabresa}

A quadrilha de assaltantes que agia em São Carlos era formada por imigrantes originários da Calábria, a maior parte deles proveniente da província de Catanzaro. A emigração dessa região apresentava uma característica notável, qual seja, um caráter marcadamente transoceânico, quando comparado a de outras regiões da Itália. Nas províncias do Norte, havia uma parcela significativa de imigrantes que se deslocavam no interior do próprio continente europeu. Na Calábria (e também na Campania) o destino era sobretudo a América. E no próprio interior da região calabresa, Catanzaro foi a província que apresentou o maior número de emigrantes. Ali a emigração tornou-se mais freqüente a partir da última década do século XIX. No período de 1892 a 1901, que inclui os anos de atuação da quadrilha Mangano, mais da metade dos calabreses emigrados ao Brasil saíram de Catanzaro. Scalise (1905, p. 10) afirma que, para os calabreses de modo geral, era mais caro emigrar para outros países ao norte da Itália do que para a 
Tabela 1

Destinos de Emigrantes Calabreses, 1876-1901

\begin{tabular}{l|rrrrr}
\hline & $1876-1881$ & $1882-1891$ & $1892-1901$ & $1876-1901$ & $1899-1901$ \\
\hline Europa & 1.376 & 3.072 & 6.762 & 11.210 & 3.677 \\
Africa & 1.354 & 11.128 & 6.579 & 19.061 & 2.183 \\
Argentina & 4.320 & 35.525 & 60.722 & 100.567 & 24.779 \\
Brasil & 5.157 & 18.228 & 45.051 & 69.036 & 13.663 \\
Estados Unidos & 1.043 & 34.098 & 59.264 & 94.405 & 26.047 \\
América & 13.035 & 94.665 & 172.485 & 280.185 & 69.583 \\
Total $^{*}$ & 15.655 & 110.109 & 185.893 & 311.657 & 75.478 \\
\hline
\end{tabular}

* Inclui outros destinos.

Fonte: Scalise (1905, p. 134-137).

Tabela 2

Destinos de Emigrantes da Província de Catanzaro, 1876-1901

\begin{tabular}{l|rrrrr}
\hline & $1876-1881$ & $1882-1891$ & $1892-1901$ & $1876-1901$ & $1899-1901$ \\
\hline Europa & 29 & 99 & 336 & 464 & 200 \\
África & 757 & 4.240 & 2.497 & 7.494 & 590 \\
Argentina & 19 & 7.788 & 13.125 & 20.932 & 6.970 \\
Brasil & 49 & 1.348 & 25.583 & 26.980 & 7.000 \\
Estados Unidos & 12 & 13.033 & 35.326 & 48.371 & 17.752 \\
América & 368 & 25.351 & 74.982 & 100.701 & 32.634 \\
Total $^{*}$ & 1.154 & 29.687 & 77.880 & 108.721 & 33.461 \\
\hline
\end{tabular}

* Inclui outros destinos.

Fonte: Scalise (1905, pp. 134-137).

América. As Tabelas 1 e 2 apresentam dados relativos aos destinos da emigração calabresa, em particular de Catanzaro.

Scalise ainda aponta que a cada dez emigrantes, sete eram homens e oito adultos, a grande maioria com profissões rurais: pequenos proprietários, trabalhadores rurais contratados ou diaristas. Apenas um quarto deles viajava acompanhado de familiares, e a faixa etária mais comum era entre 15 e 35 anos.

A literatura (cf. Foerster, 1919) aponta um conjunto heterogêneo de causas que concorreram para a generalização da emigração em todo o sul da Itália. Embora intimamente inter-relacionadas, elas podem ser, por motivos didáticos, agrupadas em causas naturais e sociais. Entre as primeiras, vale citar a ocorrência de secas provocadas por um regime pluviométrico que alterna- va seis meses contínuos sem chuva com seis meses de chuva forte.

Nem sempre foi assim, o que demonstra, ao menos nesse caso, a prevalência de fenômenos sociais por detrás dos caprichos da natureza. A mudança climática precipitou-se a partir da derrubada de áreas florestais desde o início do século XIX e, ironicamente, encontra-se associada à abolição dos direitos feudais (em 1806 no continente, em 1812 na Sicília) e à secularização das terras da Igreja (1855-1873). A devastação das florestas nativas em uma região de relevo acidentado predispôs o solo a erosão e deslizamentos freqüentes, o que ocasionava inundações e formação de pântanos nas terras baixas. Isso teve efeitos desastrosos sobre a agricultura. Ademais, terremotos abateram o ânimo das populações rurais. Apenas na Calá- 
bria eles foram registrados em 1854, 1870, 1894, 1905, 1907 e 1908.

Na Itália meridional, as origens da aglomeração dos camponeses em vilas localizadas em serras remontam à insegurança e à anarquia endêmicas na região, prevalecentes durante muitos séculos após a queda do Império Romano. Porém, a malária, que vicejava nas terras baixas, em decorrência da devastação ecológica do século XIX, criou um novo motivo para residir em colinas altas, longe das planícies mais férteis, onde o mosquito transmissor abundava (Blok, 2001c). O camponês tinha de se deslocar diariamente para trabalhar, o que constituiu mais um fator capaz de inibir o sucesso de pequenas propriedades.

Sobre tais causas ditas "naturais" agiram ainda a estrutura fundiária, as formas de contrato agrário e suas implicações para a renda e a produtividade dos agricultores. Acompanhado de técnicas de cultivo primitivas, o grande latifúndio permaneceu, não obstante as oportunidades de mudança desse perfil agrário. Uma delas apresentou-se com a abolição dos direitos feudais, no início do século XIX, quando de fato houve uma grande distribuição de terras pertencentes aos nobres. Muitas delas foram adquiridas por grandes proprietários de forma fraudulenta, e, das terras distribuídas aos pobres, grande parte foi, algum tempo depois, transferida a credores. Após meio século, ocorreu outra grande distribuição, relativa aos bens da Igreja. Em algumas regiões as terras eclesiais foram distribuídas mediante uma renda perpétua que deveria ser paga pelos favorecidos. Contudo, o valor do arrendamento era alto, forçando os mais pobres a renunciar a seus lotes. As imposições do Estado também concorreram para a desapropriação dos pobres. "Após a Unificação, impostos elevados forçaram muitos dos pequenos proprietários, que haviam se endividado para comprar terras, a venderem estas aos poucos que tinham capital" (Banfield, 1958, p. 145).

Nos casos em que a família lograsse reter o título de sua propriedade, o frazionaménto entre herdeiros, garantido pelo direito sucessório promulgado no novo Código Civil, inviabilizava economicamente a propriedade. Em todo o sul da Itália permaneceu, então, uma situação em que os grandes latifúndios conviviam com propriedades minúsculas, superfracionadas. "A população aumentava rapidamente e as pequenas propriedades, divididas por heranças, tornavam-se cada vez menores" (Idem, p. 145).

Tanto na grande como na pequena propriedade, outra característica marcante foi a ausência do proprietário. Na Calábria, um inquérito parlamentar sobre as causas da emigração ao final do século XIX informou que

[...] grandes proprietários são, como regra, ausentes. Os da zona costeira, com seus cultivos extensivos; os ricos - verdadeiramente grandes proprietários - vivem muito distante de suas terras. Os das zonas montanhosas são também ausentes, mas suas rendas não lhes permitem deixar a capital da província ou as adjacências; de fato, do ponto de vista agrícola, é como se habitassem do outro lado do mundo, pois visitam suas terras apenas uma ou duas vezes por ano (Foerster, 1919, p. 72).

A ausência do proprietário tornava necessário que a propriedade fosse administrada por um preposto ou arrendatário. Na Sicília, esse agente era chamado gabellotto; na Calábria, o papel cabia ao industriante (Jamieson, 1997, pp. 471-472). Esse tipo de especulador, intermediário por excelência, tratava de sublocar as terras a outros arrendatários que, por sua vez, contratavam camponeses mais miseráveis. Na província de Catanzaro, predominava o arrendamento de um ano, exceto para o cultivo de cereais, que se prolongava por quatro a cinco anos. Essas pequenas sublocações eram normalmente pagas em produtos, e raramente os contratos eram renovados. Na região da Calábria como um todo, apenas um sexto da população empregada na agricultura cultivava sua própria terra - cifra muito menor que a observada em regiões da Itália setentrional ou central. Dois terços dos agricultores (contadini) eram trabalhadores contratados, alguns com contratos anuais, mas cerca de três quartos destes era composta por miseráveis que se deslocavam cotidianamente ao mercado, antes do amanhecer, para serem contratados por dia, os giornalieri (Foerster, 1919, p. 85). 
Nesse quadro, não faltavam obstáculos para uma agricultura mais eficiente: estrutura fundiária polarizada entre latifúndios e pequenas propriedades - nas grandes, os proprietários pouco se importavam com a introdução de melhorias ou inovações, e os arrendamentos de curto prazo impeliam a práticas agrícolas danosas que retiravam o máximo da terra no menor tempo possível -; métodos de cultivo atrasados, herdados ainda do império romano; e, por fim, a destruição do meio ambiente.

Além dessas circunstâncias, como de fato vivia a população calabresa? As casas dos contadini eram pequenas e rústicas - casas-dormitório - localizadas em aldeias sobre colinas, feitas de barro, pedra, tijolos ou lava, sem água corrente ou esgoto, iluminadas, às vezes, com lamparinas a óleo, com pouca privacidade, freqüentada por animais domésticos. A rua era normalmente o espaço de sociabilidade. Uma dieta reduzida de pão seco e pouca proteína refletia-se no estado físico debilitado dos homens, ainda agravado pela malária e pelo tracoma. "Era um tempo em que qualquer erva era cozida e comida, sem sal e sem condimento, para dar ao estômago a ilusão de saciedade" (Scalise, 1905, p. 45).

A grande maioria da população era analfabeta, conseqüência do baixo investimento educacional. Os dados relativos ao censo de 1901 revelam que, se para a Itália como um todo o percentual de analfabetos (maiores de 7 anos) já era elevado (51,5\%), as taxas de alfabetização calabresas encontravam-se entre as mais baixas do país $(21,3 \%)$. Scalise reclama das depreciações comuns proferidas pelos nortistas, os quais consideram que "os calabreses são os mais analfabetos, os mais degradados e pertencem a uma outra raça ínfima, que não pode ser confundida com a nossa de privilegiados", mas reconhece que a Calábria é marcada pelo analfabetismo, "pois foi o ponto de toda a Itália meridional onde a dominação foi mais cruel e opressiva" (1905, pp. 94-97).

Nessa região, quase não existiam associações solidárias, como as sociedades de ajuda mútua, enfatizadas nos trabalhos sobre imigração e solidariedade étnica (cf., por exemplo, Baily, 1999, pp. 172216). Na literatura sobre a Itália meridional, os autores, de modo geral, criticam a falta de espírito associativo. Banfield é um dos mais enfáticos: critica o "egoísmo em todas as relações extrafamiliares", chegando à conclusão de que a "extrema pobreza e o atraso são explicados, em grande medida, pela incapacidade dos habitantes de agir coletivamente para o bem comum, ou para qualquer fim que transcenda o interesse imediato, material da família nuclear" (Banfield, 1958, pp. 9-10).

Em função desses problemas, o campo tinha poucas condições de absorver parcelas cada vez maiores da população. Com uma vivência associativa inexistente, melhorar de vida passou a significar emigrar. Como em geral acontece, não foram os mais miseráveis que emigraram. Muitos integravam uma espécie de "proletariado de proprietários": impossibilitados de tirar o sustento de suas pequenas glebas, eram forçados a buscar emprego em propriedades maiores, sob o jugo dos industrianti. Além disso, havia uma propaganda intensiva no sentido de convencer os recalcitrantes a emigrar.

Um número incalculável de agentes e subagentes da emigração espalhou-se por toda a Calábria, percorrendo as zonas rurais, encorajando os tímidos, descrevendo com cores vivas o local de destino aconselhado e, como pais amorosos, os governos aos quais serviriam; uma infinidade de folhetos de propaganda foram disseminados em cada esquina, e grandes cartazes foram afixados nas portas das igrejas, diante dos quais se aglomeravam os camponeses que logo confiavam naqueles que podiam facilitar e iluminar o obscuro e desconhecido caminho (Scalise, 1905, pp. 30-31).

\section{Banditismo e crime organizado na Calábria e nos Estados Unidos}

\section{Violência e banditismo na Calábria}

Há muito, um considerável grau de insegurança reinava em distritos rurais do sul da Itália.

Aquele que se desloca pela zona rural do altiplano calabrês, a cada passo encontra uma cruz escangalhada ou um vestígio de cruz e, em alguns pontos, chega a lhe parecer que está em meio a um velho cemitério abandonado: símbolos do 
martírio, que a piedade dos sobreviventes plantava no local ainda rutilante do sangue da vítima (Scalise, 1905, p. 66).

A longa história de banditismo, assaltos rurais e assassinatos explica, por exemplo, por que à época muitos camponeses caminhavam para o trabalho com rifles nos ombros. No continente, o relevo escarpado, que propiciava esconderijos, também facilitava crimes.

No período entre 1890 e 1897, em que se observa um baixíssimo nível salarial, o roubo na Sicília tornou-se um meio de vida (Foerster, 1919, p. 98). Ali, a vendetta (homicídios por vingança) era praticada em uma proporção cinco vezes maior que nas províncias italianas setentrionais. "Covil e refúgio de bandidos graças à sua posição quase no coração da sela dos Apeninos", a Calábria não ficava atrás. Scalise observa, em relação aos crimes de vingança, o

[...] sentimento feroz e quase selvagem, junto à massa da população, da honra familiar, sentimento em nome do qual não se transigia nenhum instante e que inexoravelmente armava a mão do ofendido, o qual, depois, refugiava-se nas florestas virgens, onde persistia no delito, e para quem a visão do sangue odiado the havia feito provar toda a volúpia do instinto primitivo. O banditismo, por essa trágica e cruenta concessão da honra doméstica, apenas sob essa rubrica, recrutava grande parte de seus militantes (1905, pp. 84-85)

A análise de Banfield exagera quanto à incapacidade de os italianos meridionais agirem de maneira coletiva, já que muitos, efetivamente, colaboravam em atividades ilegais. O banditismo endêmico da Calábria sempre envolveu a colaboração entre não parentes dentro dos bandos e certo grau de apoio do restante da população. No início dos anos de 1860, na esteira da unificação italiana, a grande onda de banditismo na Calábria representou uma espécie de levante coletivo contra o novo Estado "piemontês" e contra os latifundiários por camponeses e ex-soldados do exército dos Bourbons (Adorni, 1997; Hobsbawm, 2000, pp. 107-108). No século XX, muitos indivíduos da região meridional organizaram-se para a ação coletiva em organizações criminosas de grande por- te - Ndrangheta calabresa, Camorra napolitana, Sacra Corona Unita pugliana e Máfia siciliana -, mantendo, internamente, uma solidariedade baseada na extensão do vocabulário e dos símbolos familiares (Blok, 1974, 2001b; Hess, 1998, p. 187; Jamieson, 1997).

Se os italianos meridionais eram capazes de agir coletivamente em benefício de grupos particulares, resistiam, é verdade, em participar de projetos para o bem-estar da comunidade. Séculos de dominação estrangeira, de governos arbitrários e corruptos e de dominação local por latifundiários deixaram os camponeses dessa região profundamente desconfiados da autoridade pública, o que provocou a canalização da ação coletiva para vias informais, personalistas e clientelísticas, contribuindo para um ambiente de insegurança e violência privada (Adorni, 1997; Gambetta, 1992, pp. 93-131; Hess, 1998, pp. 14-46). Em 1901, um magistrado calabrês, em artigo de jornal, denunciou

[...] o absenteísmo do governo central, a pouca retidão dos seus funcionários, [que] produziram no ânimo desta população desconfiança, a maior possível na Justiça, a qual não sabe proteger os fracos da prepotência dos fortes [...]. É lógico que todos os fracos, em vez da justiça dispensada nas salas do Fórum, têm recurso àquela praticada com o fuzil, com o punhal ou com a navalha (apud Jamieson, 1997, p. 471).

Eric Hobsbawm (1959; 2000), ao fazer uma distinção entre criminosos predatórios, que roubam de qualquer um, e "bandidos sociais", que constituem um tipo de "rebelde primitivo", vitimando os ricos e conquistando o apoio dos pobres, reconhece a existência de um grande leque de casos intermediários, e que muitos "bandidos sociais" gozam da proteção de facções da elite local. As teses desse autor têm estimulado bastante o debate sobre o banditismo em várias partes do mundo. Elaborada originalmente pelo antropólogo holandês Anton Blok (2001a), ${ }^{3}$ a linha principal de crítica a Hobsbawm reconhece o mito popular do "bandido social", mas afirma que, na realidade, os bandidos geralmente colaboram com elites locais, sobretudo latifundiários, e que sua atuação tende a impedir, em vez de facilitar, a mobilização 
dos camponeses. ${ }^{4}$ Por causa de seu banditismo endêmico, esses autores privilegiam a análise da Itália meridional (cf. também Blok, 1974).

Sem o apoio da população ou de parte da elite, segundo Hobsbawm, os bandidos não sobreviveriam por muito tempo. O autor fornece vários exemplos de colaboração entre bandidos e elite, como, por exemplo, as famílias de latifundiários que usavam os serviços de bandidos para se vingar ou lucrar às expensas de outras famílias proeminentes (2000, pp. 99-104). As autoridades militares encarregadas de reprimir o banditismo na Itália meridional, após a unificação, reclamavam que não apenas os camponeses, mas também alguns latifundiários protegiam os bandidos. Um comandante militar escreveu de Catanzaro, província de origem da maior parte do bando Mangano, em 1864:

Senhores dos mais influentes pela posição e riqueza não mostram nenhum escrúpulo em proteger o banditismo de todos os modos possíveis [...]. [Convém] aos grandes proprietários, porque por meio dos bandidos, que eles protegem, executam suas vinganças privadas, asseguram suas propriedades e continuam a exercer uma espécie de autoridade feudal, da qual foram despojados com a queda do governo borbônio (apud Adorni, 1997, pp. 295-296).

A extorsão de dinheiro mediante ameaças à vida e à propriedade era uma tática de banditismo bastante conhecida entre a população calabresa. Em 1862, referindo-se especificamente a Catanzaro, outro militar escreveu em relatório reservado:

É sistema dos bandidos escrever bilhetes aos proprietários exigindo deles quantias de dinheiro, objetos preciosos, vestes ou armas, sob ameaça à vida e ao patrimônio, e estes, sob o pesadelo do medo, quase sempre mandam as quantias e os objetos exigidos; e também, enquanto isso, muitas vezes acontece de um proletário qualquer usar de tal meio com o nome de um bandido para ganhar dinheiro e gozá-lo em paz, porque acobertado por esse estratagema (apud Adorni, 1997, p. 295).
Em suas tentativas de extorsão, a quadrilha Mangano, em São Carlos, apenas transpunha um procedimento do banditismo calabrês para um novo contexto.

\section{Conseqüências da migração calabresa para o crime na Calábria e no Estado de São Paulo}

É significativa a observação de Foerster de que o banditismo na Basilicata e na Calábria havia sido reduzido menos pela ação policial do que pelos efeitos da emigração. Scalise já havia observado, com certa satisfação, que o fenômeno da emigração tinha solucionado o problema do banditismo:

O estado psíquico e social da Calábria teria permanecido tal como era, ou até piorado, inevitavelmente, com o agravamento da situação econômica, se a resolução heróica da emigração não o houvesse subvertido pela raiz [...] a emigração solucionou o banditismo e a esse fenômeno devemos o fato de hoje nas florestas da Sila e do Aspromonte não mais fervilharem os ferozes e inevitáveis expoentes da fome e da opressão (1905, pp. 67-69).

Isso se devia, segundo Scalise, ao fato de ser a "massa dos imigrantes composta de indivíduos que, pela prevalência do sexo masculino e pela idade, são mais inclinados a delinqüir". Podemos acrescentar que a emigração também constituía uma alternativa atraente para os foragidos da justiça. Em vez de se refugiar nas florestas e montanhas, sustentando-se pelo banditismo, tanto os vingadores da honra familiar como os criminosos comuns podiam embarcar para a América.

Scalise analisou ainda a variação da taxa de homicídios, por região, em toda a Itália entre os censos de 1881 e 1901, época da grande emigração de italianos para o Brasil. Nos dois períodos discriminados na Tabela 3, a Calábria esteve entre as três regiões da Itália onde mais homicídios per capita ocorreram, mas a taxa diminuiu de modo significativo $(-41,7 \%)$. As cifras anuais dos extremos do período são ainda mais significativas: no ano de 1880 registraram-se na Calábria 525 ho- 
Tabela 3

População e Homicídios (Calábria, 1880-1900)

\begin{tabular}{l|r|r}
\hline População & 1881 & 1901 \\
& 1.257 .883 & 1.370 .208 \\
\hline Média anual de homicídios & 423 & 268 \\
Homicídios/100 mil habitantes & 33,6 & 19,6 \\
\hline
\end{tabular}

micídios (41,7/100 mil habitantes), enquanto, em 1900, essa mesma cifra caiu para 231 (16,9/100 mil habitantes). Scalise também observou a diminuição de casos de agressão pessoal registrados na região: no período de 1887 a 1889, foi apurada uma média anual de 9.106 agressões, ao passo que nos anos de 1899 e 1900 , essa média foi de 7.175 casos. ${ }^{5}$

Se a emigração de grande número de homens jovens, justamente a categoria demográfica mais implicada em agressões e homicídios, afastou muitos crimes da Calábria, é lógico pensar que também levou ao aumento nas taxas de crime violento no Estado de São Paulo, um dos principais destinos dos calabreses. Estes e outros italianos meridionais eram super-representados entre os italianos acusados de crimes em São Carlos no período de imigração mais intensa. Não incluindo os participantes da quadrilha Mangano, conseguimos identificar a origem regional de 274 dos 421 italianos acusados de crimes em São Carlos no período entre a abolição e a Primeira Guerra Mundial: $70,1 \%$ eram meridionais e, entre os meridionais acusados, 40,8\% eram calabreses. Incluindo aqui os 38 indiciados por participação na quadrilha, ${ }^{6}$ os calabreses constituíram $37,3 \%$ dos italianos e $50,7 \%$ dos meridionais acusados.

Em contrapartida, o aumento nos delitos contra os bons costumes e contra a ordem familiar na Calábria (média anual de 373 entre 1880 e 1886 e de 571 entre 1896 e 1900) parece se explicar pelo desequilibrio entre os sexos, decorrente de uma emigração de caráter eminentemente masculino (inclusive a emigração desacompanhada de muitos homens casados), que levou a certo relaxamento dos laços familiares. Em 1901, de cada cem mulheres casadas na Calábria, dezesseis tinham os maridos ausentes. A esse respeito, Scalise afirma:
[...] o aumento dos delitos contra os bons costumes e a ordem da família [ocorre] graças ao excessivo desequilíbrio de sexos e ao número inimaginável de esposas que permanecem sós e privadas do esposo, do vigilante custódio da família e de sua honra (1905, pp. 80-81).

A falta de homens na Calábria correspondia a um excedente de homens calabreses na Améri$\mathrm{ca}$, produzindo agressões entre imigrantes motivadas por ciúmes ou entre homens competindo por mulheres, tendência que se verifica nos inquéritos e processos criminais de São Carlos. Um jovem integrante da quadrilha Mangano, por exemplo, numa noite de 1896, baleou um português que com ele havia brigado por ciúmes da "rapariga" brasileira que dormia com o calabrês.?

\section{Italianos e crime organizado nos Estados Unidos}

Ao contrário do que se observa no Brasil e na Argentina, o crime organizado de italianos e descendentes foi notável nos Estados Unidos. Entretanto, é importante observar que as redes mafiosas se estabeleceram somente em algumas das cidades norte-americanas com grande concentração de italianos. A literatura sobre as origens históricas das máfias norte-americanas (Hess, 1998, pp. 161-174; Nelli, 1970, pp. 125-155, e 1976) aponta quatro fatores para explicar seu crescimento em cidades como Nova York, Chicago e outras menores: 1) elevada concentração de italianos meridionais - cerca de $80 \%$ dos imigrantes italianos nos Estados Unidos (Klein, 1989, p. 112) -, o que fortaleceu a solidariedade étnica, consolidando a coesão interna das quadrilhas e garantindo o silêncio da comunidade italiana; 2) falta de outras opções de mobilidade social, especialmente nas cidades mais antigas, devido à presença de outros grupos imigrantes já estabelecidos; 3) corrupção da polícia e controle de políticos locais, por meio, sobretudo, da capacidade de arregimentar os votos de italianos nessas cidades, permitindo a impunidade das quadrilhas; e 4) imigração de muitos foragidos e outros criminosos italianos em busca de novas oportunidades. Certamente, a falta de oportunidades e a existência de comunidades re- 
lativamente homogêneas - originárias de uma região conhecida pelo banditismo e outras formas de crime organizado - favoreceram o desenvolvimento de redes criminosas. Mas somente o grau de corrupção na política e na polícia locais pode explicar a diferença entre cidades norte-americanas com intensa presença da Máfia e outras, como Boston, onde, apesar da grande concentração de italianos meridionais, se observou pouca atividade mafiosa (Nelli, 1970). Os imigrantes criminosos concentravam-se em cidades que, de certa forma, garantiam seu "exercício profissional", justamente onde era possível corromper as autoridades locais.

A proibição de bebida alcóolica apenas criou novas oportunidades para as gangues criminosas aumentarem seu lucro. Nas disputas entre quadrilhas para controlar o tráfico de álcool, os italianos, em geral, venceram outras gangues étnicas, compostas sobretudo por irlandeses ou judeus, o que contribuiu muito para a consolidação do poder das máfias.

Aqui interessa-nos mais a fase anterior à Lei Seca. Em uma análise das origens da Máfia de Chicago, Humbert Nelli (1970, pp. 125-155) mostrou que o crime "organizado" de italianos na cidade começou, ao final do século XIX, com pequenas quadrilhas, muitas vezes compostas de criminosos profissionais da Itália, especializados em roubar de outros italianos mediante a extorsão e a chantagem. Essas quadrilhas, conhecidas coletivamente como a Black Hand, operavam com relativa impunidade porque se beneficiavam com a corrupção da polícia local, a "solidariedade" de italianos, que olhavam as autoridades norte-americanas com suspeita e tinham medo de falar, e o descaso do resto da população, que pouco se importava com crimes limitados à comunidade italiana. Em outras cidades, como Boston, com elevada concentração de italianos meridionais, mas com pequenos índices de corrupção policial e política, as quadrilhas não prosperaram.

Nas primeiras duas décadas do século XX, algumas quadrilhas italianas de Chicago cresceram e aumentaram sua lucratividade entrando no ramo dos "vícios proibidos", principalmente o jogo e a prostituição. Elas tinham fregueses de todas as etnias e eram favorecidas pela corrupção de políti- cos locais e da polícia, os quais protegiam esses negócios da interferência da justiça. Uma parte importante desse sistema era a capacidade de os mafiosos arregimentarem votos italianos para políticos que, por sua vez, protegiam seus negócios ilícitos. Após a promulgação da Lei Seca, essas foram as quadrilhas que entraram na disputa para dominar o tráfico de bebidas alcóolicas na cidade. É bem provável que a solidariedade étnica tenha ajudado as quadrilhas italianas - que nem sempre eram 100\% italianas - a vencer quadrilhas de outras etnias, muito embora, mesmo no auge de $\mathrm{Al}$ Capone e de sua organização, os italianos nunca tenham conseguido o monopólio do crime organizado em Chicago (Dinnerstein e Reimers, 1999, p. 169). Além da lealdade familiar e da tendência a suspeitar de estranhos e autoridades, características observadas na população do Sul da Itália nessa época, o forte preconceito e a discriminação dos norte-americanos contra os italianos meridionais - vistos como raça inferior e semi-selvagem devem ter fortalecido os laços solidários entre estes (Jacobson, 1998).

\section{Hipóteses sobre a ausência relativa do banditismo e do crime organizado entre imigrantes italianos no Brasil}

Mesmo tendo em vista as diferenças significativas entre o Oeste paulista, a Calábria e as cidades norte-americanas, essa discussão permite avaliar algumas hipóteses para explicar a quase ausência de quadrilhas etnicamente organizadas entre imigrantes italianos no Brasil.

Primeiro, a literatura comparativa mostra que havia mais oportunidades para a mobilidade social dos italianos no Brasil e na Argentina do que nos Estados Unidos. Herbert Klein (1989) apresenta evidências de que, em comparação com os Estados Unidos, os italianos no Brasil e na Argentina tinham maiores oportunidades para adquirirem terras ou para virarem donos de estabelecimentos comerciais ou industriais (cf. também Baily, 1983, 1999). Na ausência de outras possibilidades, certamente o crime se torna mais atraente para indivíduos ambiciosos e empreendedores. 
Podemos questionar, porém, se as oportunidades para a primeira geração de italianos em São Paulo foram suficientes para anular os atrativos da criminalidade. Muitos conseguiram comprar sítios ou pequenas lojas, mas poucos enriqueceram. A vida dos integrantes da quadrilha Mangano demonstra que alguns imigrantes não se interessavam em trabalhar a vida inteira para dar melhores oportunidades aos filhos, preferindo enriquecer rápido com atividades arriscadas e voltar para a Itália. Para os calabreses, segundo Zuleika Alvim (1986), a vida rural estava associada à miséria. Portanto, eles geralmente não compartilhavam o sonho, tão comum entre os camponeses da Itália setentrional, de adquirir terras e tornar-se pequenos agricultores independentes, e sua aversão a servir os fazendeiros provavelmente era maior que a dos setentrionais. Tanto a pesquisa de Boris Fausto (1984), na cidade de São Paulo, como a nossa em São Carlos mostram que havia certo número de italianos dispostos à prática de furtos, arrombamentos e assaltos como estratégia de sobrevivência e de mobilidade social. Recrutas potenciais para o crime organizado italiano não faltavam.

Em segundo lugar, no Brasil, a mistura de italianos de diferentes origens pode ter dificultado a solidariedade do grupo, elemento importante tanto para a coesão interna das quadrilhas norte-americanas, como para a tendência generalizada entre os italianos de não colaboração com a polícia, o que se observava no Sul da Itália e nos Estados Unidos. Contudo, os calabreses e outros italianos meridionais chegaram ao Brasil em número suficiente para se concentrar em certos bairros urbanos, criando as condições necessárias para o desenvolvimento de um sentimento solidário - em São Carlos, por exemplo, uma região próxima ao centro tornou-se conhecida como "Pequena Calábria". Ademais, eles se concentravam em certas categorias profissionais, como o trabalho rural assalariado (Alvim, 1986), o que também favorecia a formação de redes étnicas. Em São Carlos, as ocupações dos integrantes da quadrilha Mangano sugerem que muitos vendedores ambulantes eram calabreses. Portanto, a presença de grande número de italianos de outras regiões não pode, por si só, explicar a raridade do crime organizado italiano no Brasil.

Em terceiro, as ligações entre bandidos e elite local, sobretudo latifundiários, os quais, na Itália, exerciam um papel crucial para a sobrevivência dos bandidos, eram mais difíceis de se desenvolver no Brasil. Na primeira geração, as diferenças culturais e lingüísticas impediram tal aproximação. E, sobretudo, os fazendeiros haviam trazido os italianos para trabalhar em suas lavouras e estavam preocupados em controlálos; quando precisavam de capangas, preferiam empregar brasileiros.

Por fim, no Brasil, sobretudo nas cidades do interior, foi difícil aos criminosos italianos corromperem a polícia e os políticos locais, pois estes já estavam comprometidos com os "coronéis". Além disso, italianos influentes não podiam controlar uma quantidade significativa de votos, já que a maior parte dos italianos não se naturalizou e, portanto, não votava. Como conseqüência, não havia moeda de troca, e as quadrilhas italianas não podiam atuar com impunidade, como era o caso em algumas das grandes cidades norte-americanas. Por conta disso, também, os italianos não tinham tanto medo de denunciar as quadrilhas.

Essa discussão sugere que os fatores críticos que explicam a ausência relativa do banditismo e do crime organizado entre italianos no Brasil eram a falta do apoio de uma parte da elite brasileira e a dificuldade de os italianos corromperem a polícia e os políticos locais. Mesmo na ausência desses impedimentos, a heterogeneidade da "comunidade" italiana teria limitado a conivência e a conspiração de silêncio aos conflitos de certos bairros e em determinadas categorias profissionais com alta concentração de italianos meridionais.

Apesar das condições pouco propícias para o banditismo italiano no Brasil, encontramos uma quadrilha relativamente grande, que aterrorizou as elites e outros moradores de um dos principais municípios produtores de café no Estado mais rico da federação, operando com relativa impunidade por mais de dois anos. A seguir, examinaremos a composição e a organização dessa quadrilha, suas relações com outros italianos e a história de sua atuação e extinção, para identificar as cir- 
cunstâncias que permitiram seu estabelecimento e sua atuação.

\section{A composição e a organização da quadrilha}

Para Charles Tilly (1990), a unidade de análise nos estudos de migrações deve ser a rede, não o indivíduo, porque são as redes que se transplantam, se reconstituem e se transformam nas migrações. A quadrilha Mangano não era uma rede de bandidos que imigrou já constituída da Itália. Dos 38 homens indiciados por participação na quadrilha, Francisco Mangano e quatro outros eram da vila de Monterosso, na Província de Catanzaro, Calábria, e certamente se conheciam antes da emigração. Esse pequeno grupo era mais velho e, pode-se dizer, mais elitizado que o resto do bando: Mangano tinha 44 anos em 1898 e era dono de uma venda no subúrbio de Vila Isabel. Antonio Farina, 46 anos, era negociante e marceneiro, estabelecido perto da estação de trem de São Carlos. Antonio Morano tinha 63 anos, era negociante volante e morava perto de Antonio Farina, aparentemente no mesmo quarteirão. Luigi Giordano, 33 anos, era carpinteiro e dono de um hotel em Torrinha. Francisco Farina, irmão de Antonio, também era carpinteiro com 33 anos e residente em Torrinha. Todos os cinco provenientes de Monterosso eram alfabetizados e casados, embora seja provável que alguns tivessem deixado suas famílias na Itália.

Tanto Hobsbawm como Blok ressaltam a importância de laços entre bandidos e elites, no sentido de que elas fornecem proteção, facilitam fugas e colaboram na venda de propriedade roubada. Não há evidência de ligação do bando Mangano com os italianos mais ricos de São Carlos, e muito menos com a elite dos fazendeiros locais, mas a quadrilha incluía integrantes ou colaboradores da pequena burguesia italiana da região, que ajudavam a esconder e vender mercadorias roubadas, e cujos negócios constituíam pontos de encontro do bando. Os donos de vendas, hotéis e restaurantes ocupavam uma posição estratégica para a formação de redes de relações e para coletar informações perti- nentes sobre viagens de ricos, carregamentos de mercadorias e movimentos da polícia. Os participantes da quadrilha com estabelecimentos comerciais em outras cidades facilitavam a mobilidade do bando, fornecendo lugares de pouso e esconderijos. Dos indiciados, um era dono de hotel em São Carlos, outro tinha restaurante em Torrinha, e outros três se diziam negociantes.

Seis dos indiciados foram identificados como negociantes ambulantes. Se acrescentarmos dois carroceiros e um "carteiro particular", pelo menos nove indiciados tinham profissões que implicavam um grau elevado de mobilidade. Isso é consistente com a observação de Blok (2001a, pp. 2627) sobre a tendência do banditismo em envolver "profissões móveis", que trazem vantagens, porque facilitam a coleta de informações sobre vítimas em potencial e permitem o deslocamento sem levantar suspeitas. Dos outros indiciados com profissão identificada, nove eram artesãos e somente seis eram trabalhadores braçais, entre eles camaradas, jornaleiros e serradores.

Na maioria dos casos, não fica claro se os integrantes da quadrilha haviam participado de ações de banditismo antes de emigrarem. No inquérito e no processo, aparecem evidências de que três deles já eram ladrões na Itália. Pasquale Gabarro, negociante ambulante de 53 anos, tinha cumprido pena de 24 anos na Itália. ${ }^{8}$ Vicente de Mondi Ceriani, segundo testemunha, veio de uma família de ladrões:

[...] elle declarante conhece toda a familia de Cerianni da Italia e que todos são criminosos; que Cerianni era constantemente preso por delictos que praticava, tendo até esta data um seu irmão cumprindo sentença e um outro fallecido no carcere; que alem destes dois irmãos de Cerianni, há também uma irmã que é uma refinadíssima ladra. ${ }^{?}$

Porém, não há esse tipo de evidência a respeito dos outros. Com certeza, eles conheceram o banditismo como forma de ação coletiva na Calábria, onde era comum, mas não podemos dizer mais do que isso sobre sua experiência anterior.

Além dos cinco de Monterosso, os outros homens indiciados vieram de várias aldeias e vilas da Calábria, principalmente da província de Catanza- 
ro. Não há indicação de naturalidade para dez deles (todos italianos, a maior parte foragidos), mas é pouco provável que não fossem meridionais, já que os outros 28 eram todos da Calábria. Desses, dezenove eram de Catanzaro, dois de Cosenza, dois de Reggio di Calábria e cinco sem indicação da província. Incluindo os de Monterosso, temos informação sobre aldeia ou vila de nascimento em 24 casos. Havia pouca concentração: dois de Torre de Ruggiero, Catanzaro, dois de Corigliano Calabro, Cosenza, dois irmãos de Dinami, Catanzaro, dois irmãos de Palmi, Reggio di Calábria. Os outros vieram de onze municípios distintos. Com origens tão dispersas, é evidente que a maior parte não tenha se conhecido na Itália, e que o bando só tenha se formado em São Carlos, onde foi estabelecida a ligação de pequenas redes ou indivíduos à rede central de Monterosso.

Havia certa concentração de calabreses em São Carlos, o que facilitou a formação e a atuação da quadrilha. As informações contidas nos registros de casamento paroquiais, única fonte disponível para se inferir a procedência regional dos italianos em São Carlos, indicam que, depois dos vênetos de longe a categoria mais numerosa, os calabreses constituíram o segundo maior grupo de noivos italianos. Na cidade, as ruas localizadas entre a estação ferroviária e o mercado municipal, principal zona de comércio da cidade, eram informalmente conhecidas como "Pequena Calábria".

É pouco provável que os calabreses tivessem uma identidade regional forte antes de emigrar. A literatura sobre o sul da Itália naquela época afirma que as identidades eram sobretudo locais. Os calabreses tinham em comum o dialeto e a cultura regional, em que o banditismo era considerado um meio de sobrevivência para foragidos, uma via de mobilidade social e, às vezes, segundo Hobsbawm, uma forma de vingança e resistência contra os ricos. No Brasil, entretanto, desenvolveu-se uma identidade regional que contrastava com a dos brasileiros e também com a dos imigrantes da "Alta Itália", como se dizia na época. É comum, nos processos criminais, os outros italianos referirem-se a eles como calabreses e comentarem a impossibilidade de entender seu dialeto. Esse tipo de categorização tende a criar fronteiras étnicas e a reforçar a identidade do grupo (Poutignat e Streiff-Fenart, 1997). A origem regional comum e a nova identidade certamente ajudaram o desenvolvimento da confiança e da cumplicidade necessárias para atividades criminosas colaborativas, e o dialeto, a guardar segredos dos não calabreses.

A epidemia de febre amarela que grassava pelo município de São Carlos naqueles anos facilitou a atuação da quadrilha. Os bandidos enfrentavam os mesmos riscos que o restante da população, mas a doença criou boas oportunidades para roubos. O vírus matava pessoas, mas deixava sua propriedade intocada, e grande parte da elite refugiouse em outros municípios, deixando lojas e casas desprotegidas. A doença também causou várias baixas na polícia e desorganizou as forças da ordem.

É possível distinguir entre o grupo que realizava os assaltos e a rede de colaboradores, que fornecia informações sobre vítimas potenciais, ajudava na venda de bens roubados e dava apoio logístico, na forma de abrigo, comida, transporte e esconderijo. De maneira geral, os assaltantes eram mais novos e mais pobres, com forte tendência para serem negociantes ambulantes, artesãos ou trabalhadores braçais. A rede de apoio incluía sobretudo homens maduros e donos de negócios com endereço fixo. Alguns indivíduoschave, como Francisco Mangano, pertenciam a ambos os grupos. Os "espiões" podiam ser um amigo ou conhecido que falava livremente sobre o que sabia de possíveis vítimas, ou ainda integrantes do bando enviados especificamente para coletar informações ou seguir vítimas potenciais.

O bando era pouco hierarquizado, caracterizando-se mais como uma rede do que como uma organização. Francisco Mangano tinha o respeito de todos e geralmente liderava as operações de maior vulto, mas segmentos menores da rede também realizavam assaltos de maneira independente. Michelangelo Monteleone reivindicava uma posição de liderança, sem, ao que parece, confrontar-se com Mangano. A colaboração de um número relativamente grande de pessoas sem hierarquia é um bom indício de que havia entendimentos compartilhados e certa solidariedade interna no bando, apesar da ausência de rito de ini- 
ciação ou outro ritual formal que afirmasse a identificação e a solidariedade entre os membros do grupo - nada além de um aperto de mão antes de saírem para um assalto. Sua composição quase inteiramente calabresa - com a colaboração de um ou dois sicilianos, cujos nomes não constam no processo, e de duas portuguesas, mulher e ex-namorada de integrantes calabreses - sugere que a solidariedade regional ou étnica dos calabreses foi essencial para a coesão da quadrilha.

Um exemplo curioso de solidariedade envolveu Antonio Parise, trazido por Mangano de São Paulo para ajudar na realização de um assalto ao trem de pagamento. O pé de Parise foi esmagado por um trem, quando ele, aparentemente, tentava serrar o trilho, e membros da quadrilha organizaram uma subscrição para ajudá-lo. Michelangelo Monteleone, comovido pelo acidente, afirmou que: "era um companheiro seu muito valente e que já havia feito seis mortes". ${ }^{10}$ Mas a solidariedade interna da quadrilha também se revelou limitada em várias desavenças sobre a divisão da propriedade roubada.

\section{Relações do bando com a comunidade italiana}

É evidente que vários integrantes da quadrilha viam o banditismo como meio de mobilidade social. Em declarações e conversas com pessoas que, mais tarde, depuseram como testemunhas o principal propósito dos assaltos não tinha relação com qualquer forma de protesto social, ao contrário, o intuito era enriquecer e voltar para a Itália.

Apesar de a quadrilha estar distante do modelo de banditismo social que Hobsbawn elabora, havia um elemento inegável de vingança social nos assaltos a fazendeiros, nas ameaças de assassinatos de autoridades locais e nas fantasias que alguns membros do bando relataram a testemunhas. Esse aspecto de atuação e de auto-imagem talvez tenha atraído certo nível de apoio e cumplicidade entre outros italianos pobres, inclusive os setentrionais, para os quais não faltavam razões de aversão aos fazendeiros e às autoridades.
Os integrantes da quadrilha odiavam os fazendeiros, isso é patente nos autos. Há indícios de que vários deles haviam trabalhado em fazendas. Rafael Sabatine, segundo o testemunho de um parceiro, assassinara o administrador de uma fazenda dois anos antes de sua prisão. Em outra ocasião, ele ficou escondido no mato durante dois meses "por causa de um barulho que fez em uma fazenda". ${ }^{11}$ Vicente Ceriani havia trabalhado como camarada na fazenda de Bento Carlos de Oliveira, mas, segundo a declaração de outro réu, foi descoberto passando notas falsas aos colonos e fugiu da fazenda. Como o fazendeiro o procurava, Ceriani "fez algumas esperas no intuito de matá-lo". ${ }^{12}$ Ademais, os vendedores ambulantes do bando talvez tenham experimentado a prepotência e a violência dos fazendeiros e seus administradores, que, normalmente, não permitiam a entrada, sem permissão de estranhos nas fazendas. Além disso, é provável que os calabreses já nutrissem certa antipatia pelos latifundiários na Itália e que suas experiências nas fazendas de café tenham tão-somente confirmado o ódio aos latifundiários em geral. Em uma carta (escrita em "italiano viciado"), tentando extorquir dinheiro do fazendeiro coronel Leopoldo Prado - delegado em exercício -, os líderes do bando declararam que o assalto ao fazendeiro Joaquim Botelho de Abreu Sampaio foi "um serviço à sociedade", e assinaram a carta como "Sociedade Anarchista Italiana da Calábria" ( $A$ Opinião, 22/12/1897). Isso provavelmente foi mais uma tentativa de assustar o coronel, do que uma declaração ideológica.

Aparentemente, o bando escrevera cartas a vários fazendeiros "pedindo dinheiro e ameaçando-os de morte", mas só chegou a incendiar a fazenda de José Ignácio de Camargo Penteado. ${ }^{13}$ É provável que eles tenham começado a assaltar fazendeiros e administradores de fazendas porque suas tentativas de extorsão fracassaram. Assaltos bem-sucedidos ocorriam em meio a várias tentativas frustradas, graças a informações errôneas que, às vezes, os obrigavam a permanecer dias escondidos no mato à espera do fazendeiro.

Se a quadrilha tivesse restringido suas atividades à extorsão e a assaltos a fazendeiros e outros indivíduos abastados, talvez pudesse ter ganho cer- 
to apoio ou tolerância popular. Ao que parece, muitos camaradas e colonos alimentavam fantasias de incendiar fazendas como vingança pelos abusos sofridos. No inquérito após o incêndio na fazenda de José Ignacio de Camargo Penteado por exemplo, a polícia inicialmente suspeitava de um camarada português que, poucos meses antes, tinha prometido incendiar a fazenda como vingança a uma multa imposta pelo fazendeiro. ${ }^{14}$ Nesse contexto, podese inferir que muitos imigrantes teriam apreciado a morte de um fazendeiro ou administrador. Em São Carlos, estão registrados, pelo menos, três assassinatos desse teor: um administrador de fazenda, morto por colono, um irmão de administrador, morto por camarada, e um fazendeiro, baleado por colonos (Monsma e Medeiros, no prelo).

Contudo, o insucesso das tentativas de extorsão, sobretudo quando comparado com a eficácia dessa tática na Calábria, sugere que o apoio popular ao bando, especialmente entre os não italianos, era limitado. Na Calábria, as ameaças eram mais críveis porque os bandidos podiam incendiar campos e construções ou assassinar pessoas sem oposição ou denúncias da população local. Em São Carlos, as ameaças não assustavam os fazendeiros nem outros grupos abastados o suficiente para surtir o efeito desejado pelos bandidos, pois, mesmo se aqueles não recebessem uma apreciação favorável dos imigrantes italianos de modo geral, eles podiam contar com a proteção de capangas brasileiros e da polícia. Ou seja, a divisão étnica entre italianos e brasileiros tendia a esvaziar as ameaças e a tornar ineficaz esse tipo de banditismo calabrês. Os assaltos que o bando realizou com maior sucesso dependiam muito menos da tolerância da população do que da surpresa do ataque. Cumprir ameaças era mais difícil, e dependia da anuência popular, pois, ao fazer as ameaças, o bando anunciava suas intenções e perdia a vantagem da surpresa.

Um aspecto essencial do bandido social, reconhecido até pelos críticos de Hobsbawm, é que, na imaginação popular, especialmente depois da morte, ele tende a assumir contornos heróicos, distantes, portanto, da realidade vivida em sua carreira criminosa. Ao bando Mangano certamente não faltaram ousadia e coragem. Além dos assaltos a fazendeiros e a administradores de fazendas, eles pretendiam assaltar o Banco União, arrombando a parede com dinamite, e preparavam ainda o ataque ao trem pagador da Companhia Paulista. O plano, que resultou no pé esmagado de Parise, era serrar uma parte do trilho e deixá-la no lugar, só retirando-a quando o trem se aproximasse. Antes de levar o dinheiro, eles pretendiam matar todos os sobreviventes do descarrilamento, para não deixar testemunhas. Algumas de suas artimanhas certamente poderiam divertir platéias populares, tornando-se histórias folclóricas, purificadas das crueldades cometidas. Logo depois de assaltar e espancar um vendedor português, por exemplo, eles enganaram a polícia, ao trocar de roupa rapidamente, chegando até a ajudar na busca por pistas dos assaltantes. ${ }^{15}$

Se, para ganhar o apoio popular, bastava, nas palavras de Hobsbawm, viver "sem curvar as costas", os integrantes da quadrilha eram bons candidatos a se tornar bandidos sociais. Contudo, o problema era que eles assaltavam qualquer pessoa com dinheiro ou objetos de valor, inclusive alguns trabalhadores italianos. Até mesmo os ataques dirigidos à elite acabavam muitas vezes prejudicando os pobres. As emboscadas a fazendeiros, por exemplo, geralmente visavam roubar o dinheiro de pagamento dos trabalhadores. Uma de suas ações mais ousadas a falta de respeito evidencia sua pelos interesses dos trabalhadores: eles levaram o cofre de um hotel depois de doparem vários hóspedes e os donos do estabelecimento, que eram italianos, com uma mistura de vinho e ópio oferecida pelos próprios ladrões. Mas a maior parte dos doze contos apurados na caixa-forte pertencia a camaradas e colonos hospedados no hotel, os quais certamente não eram ricos. Um dos donos chegou a declarar que não havia suspeitado do ladrão que servia o vinho porque ele era "muito amigo dele e [de] seu sócio". ${ }^{16}$

Às vezes, assaltos a trabalhadores motivaram discussão e polêmica no interior do grupo, sobretudo porque rendiam pouco. Consta no processo que, em conversa a esse respeito, Antonio Calsone disse

[...] que fazião mal em roubar pobres homens trabalhadores quando podiam roubar fazendeiros ri- 
cos como por exemplo $\mathrm{D}^{\mathrm{a}}$ Mafalda Ferraz que tinha muito dinheiro e que no dia seguinte vinha de São Paulo com oitenta contos. ${ }^{17}$

Certa vez, quando esperavam um fazendeiro passar pela estrada, chegou uma turma de camaradas:

[...] queriam, uns que fossem atacados, e outros não; que Michelangelo era um dos que insistia pelo ataque, dizendo que era preciso pegar o peixe grande e o peixe pequeno; a isto disse Cerianni que não concordava pois se tal fizessem podiam com isso lucrar uns duzentos mil réis, quando poderiam lucrar contos de réis; que em vista disto ficou resolvido que nada se fisesse e assim foi. ${ }^{18}$

Mas apesar dos conflitos internos a quadrilha, não mostrava piedade quando se tratava de dinheiro. Pode-se ler nos autos que certa vez um colono

[...] foi convidado por Paschoal Bolonha, Francisco Pillege e Luige Nery para darem um passeio e matarem o bicho ${ }^{19}$ e quando chegaram ao fim da rua General Ozorio ahi foi seguro por Luige Nery e Paschoal Bolonha que armados de facca e revólver o ameaçaram enquanto que Francisco Pillege lhe tirava de uma perneira os setecentos mil réis que ahi tinha guardado. ${ }^{20}$

Alguns integrantes eram capazes de muita crueldade por pouco lucro. Segundo Antonio Monteleone, Pasquale Gabarro tinha lhe contado que

[...] no mez de Janeiro na estrada que desta vae para Belem do Descalvado, sem, digo, se encontrou com um camarada a quem convidou para trabalhar consigo e conseguindo leval-o para dentro do matto, arrancando do revólver, o intimou a lhe entregar todo o dinheiro que levava, e, como este só tivesse quatro mil réis, tomou-lhe, deu-lhe uma surra e largou-o; que mais avante encontrando-se com outro, a quem fez a mesma intimação, conseguindo obter cinco mil réis, desfechando-lhe em seguida um tiro de revólver, matando-lhe e enterrando-lhe no lugar. [...] sabe que muitos camaradas de fazenda, foram roubados por esses indivíduos.
Ao que parece, a quadrilha pouco se preocupava em receber apoio ou ter a cumplicidade de outros italianos ou de brasileiros pobres; preferia, ao contrário, fazer ameaças de morte para garantir o silêncio de quem soubesse de suas ações. Os depoimentos do processo mostram que, apesar de desconhecerem os detalhes de assaltos, muitos italianos sabiam que se tratava de ladrões. Um dos donos do hotel, cuja caixa-forte fora roubada, quando perguntado se sabia algo sobre os outros assaltos, "respondeu que seus autores devem ser todos os indivíduos que se acham presos por serem geralmente conhecidos como gatunos". ${ }^{21}$ Outra testemunha afirmou

[...] conhecer a todos estes indivíduos como ladrões de profissão [porque] morando perto da casa de Pepino Rechelle frequentada constantemente por estes individuos, teve occasião de ver por mais de uma vez que sahiu de casa alta noite, armados de espingardas, garruchas, revólveres, faccas e navalhas, recolhendo-se sobre a madrugada, dormindo de dia ou nada fazendo, não lhe constando que exerceu qualquer outra profissão. ${ }^{22}$

\section{Desconfiança para com a polícia e o silêncio dos italianos}

O bando aparentemente assassinou um homem por ele ter falado demais. ${ }^{23}$ Em contraparti$\mathrm{da}$, alguns dos integrantes da quadrilha gostavam de alardear seus feitos a outros italianos, e não tinham medo de serem denunciados. Isso pode ser explicado apenas parcialmente pela divisão étnica entre italianos e brasileiros - dada a diferenciação marcada entre os meridionais e outros italianos, não é claro por que italianos do norte teriam protegido bandidos calabreses. Para uma análise mais detida, é preciso examinar as relações da colônia italiana com as autoridades brasileiras.

Os italianos, de maneira geral, não confiavam nas autoridades, especialmente na polícia. Como em outras cidades do Estado, o número de italianos cresceu rapidamente em São Carlos durante os anos de 1890, e as elites locais tendiam a culpar a comunidade italiana por crimes e desordens (cf. Fausto, 1984). ${ }^{24}$ Além disso, sabe-se que, 
não importa a época, os pobres no Brasil sempre sofreram abusos policiais, e nesse período de intensa imigração italiana a polícia usava os mesmos métodos costumeiros ao tratar com italianos, o que causava atritos freqüentes. Para muitos, a atuação policial era deliberadamente preconceituosa em relação à colônia. Os inquéritos policiais e processos criminais de São Carlos incluem vários relatos em que a polícia abusava da sua autoridade, e, certamente, houve muitos outros de espancamentos e abusos que as vítimas não ousaram denunciar. Havia casos, por exemplo, de policiais que espancaram e roubaram italianos, ou furtaram dinheiro de italianos presos. ${ }^{25}$ Em 1896, praças da polícia espancaram onze italianos presos em uma venda, o que levou à morte de Giuseppe Sciarra. O jornal sancarlense Ordem e Progresso fez comentários desfavoráveis sobre o caso e o cônsul italiano reclamou, perturbando o chefe de polícia do Estado. ${ }^{26}$ Segundo o que the foi informado, o espancamento se originou da rivalidade entre o dono da venda e o dono de outro estabelecimento freqüentado por policiais. Esses problemas não se limitavam a São Carlos: as reclamações do cônsul italiano ao chefe de polícia mostram que italianos sofreram a violência policial em todo o Estado. ${ }^{27}$

Por outro lado, a polícia encontrou nos italianos um grupo mais petulante, e mais bem armado, se comparado à população pobre do Brasil. Nesse contexto, não é de surpreender que tenha havido pelo menos dois casos de italianos que atiraram em policiais no centro da cidade. Em um desses eventos, o policial baleado morreu e o italiano conseguiu fugir. As testemunhas, incluindo cinco italianos, disseram que não reconheceram o assassino, o que podemos duvidar. ${ }^{28} \mathrm{O}$ outro aconteceu em plena luz do dia, diante de muitas pessoas. Segundo uma das testemunhas, o tiro de espingarda não acertou o soldado, mas "juntou muita gente, uns como que para aplaudirem e outros por curiosidade". ${ }^{29}$

Em primeiro de janeiro de 1894, a cidade presenciou uma batalha aberta na avenida São Carlos, principal via da cidade, entre italianos, que atiravam de dentro das casas, e a Guarda Nacional. ${ }^{30} \mathrm{~A}$ batalha começou logo depois de a
Guarda tentar dispersar uma multidão de italianos que a vaiava no Largo de Santa Cruz, centro comercial empreendido por italianos na cidade. Durante o tiroteio, um italiano foi baleado e morreu. Quase todos os brasileiros que depuseram no inquérito instaurado, representantes da classe média urbana, estavam convencidos de que o italiano fora baleado por um compatriota. Em contrapartida, as testemunhas italianas ou disseram que o autor do tiro fatal havia sido um oficial da Guarda ou declararam ignorância a esse respeito. Após o incidente, um dos líderes da colônia italiana, conhecido como Del Simoni, ${ }^{31}$ percorreu as ruas da cidade, segundo um farmacêutico brasileiro,

[...] gritando e chamando as armas os seus compatriotas. Quando isso fasia revelava-se perfeito anarchista e assim que descompunha com as palavras mais injuriosas, como iguais as filhos de uma puta e outras semelhantes a estes, a Guarda Nacional e aos brasileiros em geral. A proporção que elle assim procedia os italianos moradores nas ruas por onde elle passava iam se reunindo e se armando. [...] Não demorou dois grupos de italianos achavam-se formados, um mais ou menos em frente ao Hotel do Comércio, outro em frente a casa de del Simoni; grupos estes que se podia calcular num cento e tanto a duzentos homens. [...] Sabe mais que é público e notório que del Simoni procurou nessa cidade organisar um batalhão só composto de italianos com fim disia elle de distrahir-se e não auxiliar a justiça e nem o Brasil..$^{22}$

Esse relato foi confirmado por várias testemunhas brasileiras. Del Simoni dirigiu-se à estação, com um grupo armado, exigindo do chefe desta o envio de um telegrama ao cônsul italiano em São Paulo. A Guarda Nacional saiu à procura dos italianos armados, mas eles haviam se dispersado, evitando uma nova confrontação. O português Gaspar Berrance, tenente da Guarda Nacional envolvido nesse conflito, depois se tornou delegado de polícia e foi o responsável pela prisão da quadrilha Mangano.

Outros conflitos podem ser observados durante a epidemia da febre amarela em São Carlos. A atuação dos responsáveis pelo serviço sanitário, invadindo casas e removendo doentes à força, causou vários distúrbios envolvendo italianos e outros 
imigrantes, o que aumentou a desconfiança dessa população em relação às autoridades. ${ }^{33}$

O atrito agravou-se em função das tentativas desastradas da polícia em descobrir quem atuava na quadrilha Mangano. Depois do assalto ao fazendeiro Joaquim Botelho de Abreu Sampaio, o qual foi baleado e, ao ser considerado morto pelos bandidos, deixado na beira da estrada,$^{34}$ o delegado de São Carlos prendeu todos os italianos que estavam na fila do banco aguardando para depositar dinheiro, supondo, de maneira grosseira, que qualquer italiano com dinheiro seria suspeito. Logo depois teve de soltá-los por falta de provas..$^{35} \mathrm{O}$ coronel Leopoldo Prado - fazendeiro e delegado em exercício nesse período agiu de forma especialmente violenta em suas tentativas de descobrir os autores do crime. Seus métodos transparecem no inquérito a respeito do italiano Paulo Lafarina, o qual ameaçava-o de morte após ter sido preso por ele em duas ocasiões. O advogado Rodolpho Faria disse a uma testemunha que o coronel

[...] era violento e arbitrario, pois tinha por sabido arrancar a confição dos réus por meio de ameaças, tanto assim que diversos italianos se queixavam de tais excessos, que um italiano já fôra a sua casa consultal-o sobre a resolução, que tinha tomado de assassinar o Coronel Leopoldo Prado a quem elle doutor Rodolpho dissuadira desse intento, que mais tarde o mesmo individuo [...] voltava novamente ao seu escriptorio insistindo em querer realizar o assassinato do Coronel Leopoldo Prado e que elle doutor Rodolpho o ameaçara em denunciar caso elle insistisse em querer praticar o crime que em vista disso o italiano se retirara e se embarcara no trem das onze horas [...]. [I]sso era motivado pelas inúmeras prisões feitas pela autoridade para averiguações sobre o assalto do cidadão Joaquim Botelho. ${ }^{36}$

Segundo o doutor Rodolpho, que parece ter soltado vários italianos presos pelo delegado, com pedidos de habeas corpus, "por diversas vezes ouvira de diversos italianos ameaças contra a pessoa do Coronel Leopoldo Prado caso elle continuasse a prender a torto e a direito a fim de descobrir os assaltantes de Joaquim Botelho".

\section{O valor da publicidade}

Em conseqüência dos conflitos entre italianos e polícia, os membros da quadrilha Mangano não tinham muito medo de denúncias, tanto que, às vezes, os documentos sugerem que eles queriam publicidade, e não sigilo, ao menos no interior da comunidade italiana. Michelangelo Monteleone, um dos líderes do bando - negociante ambulante de 28 anos, sem moradia fixa que se hospedava muitas vezes na casa de Francisco Mangano e era o maior divulgador dos feitos do bando.

Claramente, ele queria ampliar sua fama de homem poderoso e valente. Certa vez, contou a outro negociante ambulante que não integrava o bando: "em São Carlos somos nós que mandamos; eu sou o chefe e devia também ser o delegado de polícia" ${ }^{37}$ A respeito do assalto ao fazendeiro Joaquim Botelho, ele disse a um negociante "que foi elle que mais coragem revelou na occasião [...]". ${ }^{38}$ O dono de uma hospedaria também comentou que "ouvio [Monteleone] dizer a diversos patrícios seus que era elle Monteleone quem mandava em São Carlos". ${ }^{39}$ Ao vangloriar-se de suas peripécias, Michelangelo ameaçava de morte quem contasse às autoridades, mas tudo indica que ele apreciava a divulgação de suas proezas entre os italianos.

Os outros integrantes da quadrilha não se mostravam preocupados com sua tagarelice. Ao que parece, essa publicidade lhes era conveniente. Eles também queriam ser respeitados e temidos, e Monteleone sistematicamente retratava o bando como uma organização muito mais poderosa do que era na realidade. Caracterizar a quadrilha dessa maneira - poder, ousadia, êxito e, sobretudo, impunidade - servia para atrair novos participantes. O processo indica que Michelangelo foi o principal recrutador do bando. Ele sonhava em realizar grandes assaltos e voltar para a Itália como um homem rico, e tentava estimular os mesmos desejos em possíveis integrantes da quadrilha. Em São Paulo, por exemplo, Monteleone convidou Salvatore Spadari

[...] para vir a São Carlos, aonde se tornava facil a pratica de roubos, devido á frebre amarella; alle- 
gando Spadari não poder vir a São Carlos, por ser conhecido da Policia, Monteleone insistia dizendo que viriam juntos a estação de Colonia, ali desembarcariam seguindo a pé para São Carlos, onde podiam chegar de noite e immediantamente tractariam de matar o delegado e o carcereiro e uma vez feito isto, ficariam a vontade porque os soldados estavam morrendo todos de febre amarella e que uma vez que juntassem uns oitenta contos iriam embora para a Itália. ${ }^{40}$

Em várias conversas com o negociante ambulante Rafael Lagrutencia, Monteleone narrava os assaltos e lhe convidava para participar:

Encontrando-se outra occasião em São Paulo com Monteleone, este convidou a elle declarante para vir para São Carlos, dizendo elle declarante não haver aqui interesses devido à febre amarella, Monteleone insistindo disse a elle declarante que viesse, que era uma occasião muito boa para arranjar dinheiro e que se pegava n'um individuo qualquer, se derrubava no chão e se matava e que dez mil réis que tivesse já servia [...]. Declarou mais que Monteleone lhe fez o seguinte convitte e pela seguinte forma: "Oh Raphael, você quer vir conosco para roubarmos o trem de pagamentos que traz sempre muito dinheiro? Nós somos muito companheiros, o trem quase sempre chega aqui de noite; nós vamos para fora da cidade, cortamos os trilhos, fazendo descarrilhar o trem e tomamos todo o dinheiro!?" que elle declarante, sendo homem trabalhador, não acceitou semelhante convitte. Declarou mais que egual convite recebeu de Monteleone para assaltarem o Banco União na colonia, dizendo Monteleone ser isso muito faccil porque bastantes companheiros armados de espingardas matariam as poucas pessôas que guardavam o Banco e roubariam todo o dinheiro. Declarou mais que tendo recebido diversos convittes do mesmo Monteleone para a pratica de muitos outros roubos e tendo dito a este que um dia se sahiria mal pois que podia ser preso, Monteleone lhe disse nada recear visto que havendo entre todos os companheiros feito uma sociedade se deffenderiam uns aos outros da seguinte forma: "Si algum dos companheiros fôsse preso e processado, os outros justariam advogado para sua defesa e no caso de que fossem presos muitos, ainda poderiam ser libertos por meio de um assalto á cadêa e desta maneira, dariam egualmente a liberdade uns aos outros presos à sociedade". ${ }^{41}$
Além de construir a reputação dos bandidos e recrutar novos integrantes, essas representações serviam para transmitir a impressão de poder e impunidade, intimidando os italianos para que não os denunciassem, quando questionados pela polícia. Talvez o grupo mais importante a ser controlado fosse integrado pelos participantes periféricos do bando, os quais forneciam serviços de apoio, mas não participavam diretamente nos assaltos. O carroceiro Giuseppe Giglioti, que às vezes transportava mercadorias roubadas pela quadrilha, contou

Que uma occasião, tendo elle declarante transportado desta cidade para Visconde do Pinhal alguns jacás com queijos pertencentes a Michelangelo, na volta, vindo este em sua companhia, em conversa lhe narrou o seguinte: que há tempos tinha dado um roubo na casa de um espingardeiro na rua de São Carlos e que nada tinham descoberto até agora; que igualmente se tinha dado a mesma rua um roubo de onze contos e que igualmente estava por descobrir e que no entanto n'elle tomaram parte Affonso Pugliese, Salvador Spadari, Cosme Scorsa Favo e outros cujos nomes não citou que formão uma sociedade poderosa; que ninguem pode com ella á qual elle Monteleone pertence, assim como muitos outros, narrando-lhe igualmente o assalto ao fazendeiro Joaquim Botelho [...]. Que Monteleone lhe contou ainda que esta sociedade operava em muitos logares, inclusive no sertão; que ao elle declarante despedir-se de Monteleone, este lhe disse que nada revelasse do que ouvio, por que sinão lhe cortarão a cabeça. ${ }^{42}$

O guarda-livros de Francisco Mangano negou todo conhecimento dos crimes no primeiro interrogatório porque, segundo sua confissão posterior, estava "receoso de ser assasinado por algum dos individuos envolvidos no mesmo crime que lhe é imputado, a exemplo do assassinato de Antonio Hyppolito nesta cidade, que foi victima da sua indiscripção sobre factos que não the eram extranhos". Ele confessou ter escrito as cartas ameaçando José Ignácio de Camargo Penteado, cuja fazenda foi incendiada, e admitiu que sabia de alguns dos assaltos. "Declarou mais que Mangano 
o ameaçou de morte caso elle declarante revellasse alguma cousa do que visse ou soubesse.”³

\section{Prisão e desmantelamento da quadrilha}

O que destruiu a quadrilha não foi o trabalho da polícia nem alguma denúncia de outro italiano, mas a traição interna. Depois do assalto a Joaquim Botelho, Antonio Farina, um dos que pertencia ao grupo de Monterosso, escreveu uma carta anônima denunciando vários participantes, os quais foram presos, mas, em seguida, libertados por falta de provas. Depois do roubo à casa comercial de dois turcos em fevereiro de 1898, Farina denunciou novamente os outros envolvidos, apesar de ter, aparentemente, participado da ação. Desta vez, vários integrantes contaram fragmentos do que havia ocorrido, possibilitando que o delegado prendesse a maior parte da rede em março desse ano. ${ }^{44}$ Outros acusados não foram presos, o que sugere que fugiram e nunca mais foram encontrados. O motivo dessas denúncias não é claro. É pouco crível que fosse um desejo de sair da criminalidade: dez anos depois, Farina seria preso por recepção de bens roubados. ${ }^{45}$ As desavenças sobre a divisão dos bens roubados talvez tenha motivado as delações. Os dois roubos denunciados por Farina provocaram discussões, e parece que o desentendimento sobre a divisão do que se apurou no roubo dos turcos foi especialmente intenso. Denunciar os companheiros seria, então, uma forma de vingança pela divisão desigual dos bens roubados.

O inquérito estendeu-se por vários meses, e o promotor só apresentou sua denúncia ao final de outubro. Em parte, o atraso deveu-se à epidemia de febre amarela, visto que a cadeia de São Carlos se tornou um foco de infecção, levando à morte alguns acusados e à decisão de transferir muitos dos presos. ${ }^{46}$ Domenico Putrini, um dos acusados, acometido da febre, fugiu do hospital de isolamento, aparentemente subornando o guarda e os enfermeiros. ${ }^{47}$ Em meio ao inquérito, o próprio delegado Berrance contraiu a doença, sendo obrigado a suspender as atividades até seu restabelecimento. ${ }^{48}$
Na cadeia, Michelangelo Monteleone elaborou manifestações mirabolantes e, sob alguns aspectos, revolucionárias, do poder e dos planos da quadrilha:

[...] que achando-se detido na mesma prisão em que se acha Michelangelo Monteleone, este em confidencia lhe revelou o seguinte: que pertence a uma grande associaçãó composta de cincoenta membros entre os quaes estava tractado o seguinte plano: Primeiro, os companheiros que se acham em liberdade o que se achassem em liberdade, todos reunidos assaltassem a cadêa onde se achassem presos os seus companheiros matando as sentinellas, o carcereiro e em seguida o delegado de policia Gaspar Berrance dando immediata liberdade aos companheiros; que era plano desta associação assaltar em primeiro logar ao Banco União na colonia, ao seu gerente Bento de Abreu quando este fosse a fazenda fazer pagamentos, a Vicente e por ultimo a cada um por sua vez a todos os fazendeiros ricos deste e de outros municipios [...] que fazia parte desse plano o assassinato das autoridades de São Carlos a quem em tempo dirigiram uma carta de ameaça e intimação para depositar certa quantia; [...] Que esta associação esta ramificada por diversas localidades do Estado sendo a sede principal - São Paulo. ${ }^{49}$

É impossível dizer até que ponto Michelangelo acreditava nisso, mas certamente queria intimidar os outros presos para que não falassem ao delegado o que sabiam sobre a quadrilha. Ele também aproveitava sua platéia cativa para confundir a investigação, tentando implicar vários inocentes nos assaltos. Disse a pelo menos um preso que o chefe da quadrilha era Rafael Spadari, nome que nem aparece nas declarações dos outros acusados. O delegado Gaspar Berrance acreditou em muito do que Michelangelo disse, escrevendo ao chefe de polícia que a quadrilha estava ramificada por todo o Estado e que ele, Berrance, estava ameaçado de morte..$^{50}$

Vários integrantes do bando falaram profusamente quando interrogados pelo delegado, quase sempre acusando os outros e minimizando sua própria participação. As ameaças de morte tornaram-se ineficazes, uma vez que a maioria dos membros estava presa ou foragida. Além disso, a violência do delegado era convincente o bastante 
para minar a solidariedade do grupo e superar o medo da vingança dos companheiros.

Em julho de 1898, com o restabelecimento do delegado e a divulgação das conclusões do inquérito, São Carlos entrou em clima de celebração pública. As elites da colônia italiana tiveram participação proeminente nas comemorações. O jornal $A$ Opinião $(9 / 7 / 1898)$ publicou vários artigos elogiando o delegado Berrance incluindo um escrito em italiano. Entre os que participaram de um ato público de reconhecimento a Berrance pelos serviços prestados à comunidade sancarlense estava o italiano Del Simoni, o mesmo que suscitara um levante da comunidade italiana contra a polícia no início de 1894 (A Opinião 12/7/1898). Em agosto, o professor de música Antonio Mugnai, regente da banda italiana da cidade, apresentou uma nova composição no Theatro São Carlos intitulada "Dobrado Berrance", e ofereceu, ao final da execução, a partitura ao delegado (Junqueira, 1998, p. 96; A Opinião, 2/9/1898).

\section{Conclusão}

A relativa ausência do crime organizado e do banditismo envolvendo italianos no Brasil, em comparação com a Itália meridional e com as cidades norte-americanas, certamente não se explica pela hipótese de que faltava, entre os italianos que emigraram para o Brasil, indivíduos dispostos a colaborar em empreendimentos criminosos. O bando Mangano podia chamar amigos e conhecidos de várias cidades paulistas para ajudar em ações específicas. Segundo a pesquisa de Boris Fausto (1984), não eram poucos os ladrões e os gatunos italianos atuantes na cidade de São Paulo na época de imigração em massa. Eles levaram esse tipo de ação a tal nível de sofisticação que sugere sua profissionalização no crime ainda na Itália. Entre a população de imigrantes sicilianos que chegaram aos Estados Unidos no final do século XIX e início do XX, havia uma minoria não desprezível de jovens mafiosos (chamados picciotti), os quais mais tarde passaram a atuar nas quadrilhas urbanas norte-americanas (Hess, 1998, pp. 162-163). Não há razão para supor que a na- tureza da imigração calabresa para o Brasil fosse muito diferente. Temos evidência de que alguns integrantes da quadrilha Mangano já eram criminosos na Calábria e suspeitamos que vários outros já tivessem algum grau de envolvimento com o crime antes de emigrar. O banditismo era bastante conhecido nas comunidades rurais da Calábria; estava, pode-se dizer, inserido na vida cotidiana dessa população.

A heterogeneidade da colônia italiana no Estado de São Paulo tampouco é suficiente, por si só, para explicar a raridade do banditismo e do crime organizado entre imigrantes italianos no Brasil. No período de 1878 a 1902, mais do que um terço dos imigrantes italianos que aportaram no Brasil eram meridionais, e estes se reuniam especialmente no Estado de São Paulo (Trento, 1989, p. 39). Em São Carlos, os calabreses e outros meridionais concentravam-se em certos bairros e em determinados ofícios, facilitando a conspiração do silêncio - a famosa omertà - e dificultando as investigações policiais, ainda que em menor escala se comparado à Itália ou aos Estados Unidos. A demais, a desconfiança da polícia generalizou-se entre os italianos, e o caso do bando Mangano ilustra como era possível usar a intimidação para impedir denúncias. No entanto, a presença de muitos italianos setentrionais em São Carlos talvez explique vários dos depoimentos incriminadores apurados após a prisão da quadrilha, ${ }^{51}$ assim como o evidente alívio entre as elites da colônia italiana, as quais só podiam ver a atuação dos bandidos compatriotas como uma ameaça a seus interesses materiais e uma vergonha para a comunidade.

De acordo com a evidência apresentada neste artigo, a ausência de vínculos com elites brasileiras e a dificuldade de corromper as autoridades locais explicam melhor por que o banditismo italiano não se consolidou no Estado de São Paulo. Os fazendeiros não precisavam dos serviços de bandidos italianos porque já tinham capangas brasileiros, que, alias, eram mais confiáveis para a repressão de imigrantes. Em relação à corrupção da polícia, era praticamente impossível, já que os "coronéis" mantinham o controle da política e das autoridades locais. Sem ter capacidade de neutra- 
lizar as forças repressivas do Estado, os bandidos italianos no Brasil não gozavam da impunidade nem sempre podiam contar com o silêncio da comunidade italiana, sobretudo se levarmos em conta a heterogeneidade desta.

As circunstâncias particulares que permitiram à quadrilha Mangano atuar com impunidade por mais de dois anos em São Carlos reforçam nossa explicação pelo fato de que o banditismo italiano no Brasil tenha sido bastante raro. Acreditamos que o sucesso dessa quadrilha resultou da combinação de dois fatores, a saber, certa concentração de calabreses em São Carlos, sobretudo em alguns bairros da cidade, e a epidemia de febre amarela entre 1896 e 1898, que atingiu gravemente o município e neutralizou as forças da ordem.

Embora ainda não existam dados conclusivos sobre o número de calabreses no município, há indícios de que era relativamente alto. Exemplo disso é o fato de existir na cidade uma zona chamada "Pequena Calábria", além da presença expressiva de calabreses nos processos criminais, como réus ou vítimas, e ainda do número considerável de noivos calabreses que constam na cúria diocesana. Essa concentração étnica teria facilitado o recrutamento de uma rede de participantes e colaboradores, assegurando o silêncio de pelo menos uma parte da colônia italiana.

A epidemia afugentou os mais abastados, desorganizou a polícia e abriu espaço para a ação do bando. As vantagens de propriedades sem moradores e de soldados doentes ou mortos são evidentes. Além disso, a ausência das elites permitia uma atuação mais aberta, porque o grupo mais propenso a colaborar com a polícia e mais interessado em denunciar o bando acabou por ausentar-se da cidade. Dessa maneira, a epidemia que se alastrou por São Carlos facultou aos bandidos, temporariamente, a mesma impunidade de que seus congêneres na Itália e nos Estados Unidos gozavam por causa da proteção de parte das elites ou da corrupção policial. São Carlos servia, inclusive, como base segura para assaltos e arrombamentos em municípios vizinhos.

Este caso excepcional do banditismo italiano no Brasil também fornece evidências relevantes sobre as formas de solidariedade e as clivagens na comunidade italiana. O entendimento mútuo dos calabreses e suas disposições antiestatais e antilatifundiárias ajudaram na cooperação interna do bando. Ademais, a falta de uma definição clara das fronteiras da quadrilha, no sentido de saber quem era ou não integrante, o que se evidencia com a ausência de rituais de iniciação, e o fato de eles não se preocuparem em manter suas atividades em sigilo sugerem que os bandidos contaram com a anuência da maioria dos calabreses.

Nas fontes disponíveis, é mais difícil perceber as atitudes dos italianos setentrionais. Sabemos que o preconceito contra os meridionais, considerados ignorantes, pouco civilizados e violentos, era amplamente difundido no Norte da Itália nas primeiras décadas após a unificação. No Brasil, as diferenças regionais demoraram em se diluir, apesar dos brasileiros colocarem todos os italianos na mesma categoria. Nas entrelinhas dos processos, pode-se observar a evidência do preconceito antimeridional. Os calabreses são chamados, por outros italianos, de "calabreses", ao passo que quase nunca se encontra referências às origens regionais de vênetos, friulanos ou piemonteses. Essa tendência nominativa tem um paralelo no hábito, evidente nos autos da época, de se referir aos negros brasileiros como "pretos", e não como brasileiros. Da mesma maneira que os negros não eram aceitos como cidadãos e semelhantes por brasileiros brancos, os calabreses eram vistos pelos outros italianos como um grupo estranho e mal assimilado pela civilização italiana. Mais tarde, as clivagens no seio da colônia italiana no município foram expressas pela fundação, em 1900 e 1902, de duas sociedades distintas: a "Meridionali Uniti Vittorio Emmanuele III" e a "Dante Alighieri", respectivamente. A primeira congregava, conforme sua denominação explicita, os italianos do sul (Truzzi, 2000, p.74).

Devido ao preconceito contra os calabreses e aos assaltos da quadrilha a italianos, é duvidoso que italianos de outras regiões apoiassem ou aplaudissem as atividades do bando. Ao mesmo tempo, fica evidente na leitura do processo criminal que muitos suspeitavam de suas atividades, mas não os denunciavam, sobretudo por causa do 
medo e da desconfiança em relação à polícia. Isso não era específico a São Carlos e, portanto, não pode explicar por que essa cidade, e não outras, constituiu uma base adequada para o banditismo naqueles anos. Entretanto, juntamente com a existência de uma comunidade significativa de calabreses e a epidemia da febre amarela, a desconfiança da polícia, generalizada entre os italianos, facilitou, com certeza, a atuação do bando. Tudo indica que grande parte dos italianos se sentia incomodada não apenas pela quadrilha mas também pela polícia, e não queria colaborar com nenhum dos lados. De fato, tanto a quadrilha como a força pública costumavam usar de violência para intimidar e roubar trabalhadores italianos.

Embora não tenhamos dados sobre as origens regionais das elites italianas que celebraram a prisão da quadrilha, é mais provável que fossem setentrionais. No processo contra a quadrilha Mangano, aparece uma pequena burguesia calabresa representada por donos de vendas, restaurantes e pensões, mas não temos notícia da presença de italianos meridionais entre os grandes comerciantes da cidade na última década do século XIX. Na época de atuação da quadrilha Mangano, pelo menos um italiano, Aurelio Civatti, já era fazendeiro importante em São Carlos, e se tornaria o primeiro vereador de ascendência italiana nesse município (Abreu, 2000). Ou seja, já existia uma pequena elite italiana, e muitas de suas preocupações, sobretudo no que diz respeito a crimes contra o patrimônio e a ordem públi$\mathrm{ca}$, eram concordantes com as da elite brasileira. Em meados de 1897, por exemplo, Civatti sofreu o incêndio criminoso da máquina de beneficiar café de sua fazenda. ${ }^{52}$ Parece-nos que a chegada de cada vez mais italianos pobres, entre eles parcelas de meridionais, considerados, por sua vez, perigosos e pouco civilizados, criou certa aproximação entre italianos abastados e a classe dominante brasileira. A transformação de Del Simoni, de líder de um protesto armado contra a Guarda Nacional a adulador do delegado Berrance, é emblemática das mudanças por que passava a elite italiana da cidade.

\section{NOTAS}

1 Fundação Pró-Memória de São Carlos, Processos Criminais, caixas 272 e 273, n. 90, 1898, Francisco Mangano e outros, depoimento de José de Araújo Cintra no inquérito, 6/1/1896; João Manoel de Campos Penteado, delegado em exercício, São Carlos, a Bento Bueno, chefe de polícia, 26/12/1895; Arquivo do Estado de São Paulo, C02803, Polícia, 1895; A Opinião (São Carlos), 9/7/1898.

2 Fundação Pró-Memória de São Carlos, Criminais, caixa 333, s./n., 1897, Paulo La Farina.

3 O artigo de Blok criticando Hobsbawm foi publicado originalmente em 1972

4 Para uma boa introdução à literatura sobre banditismo na América Latina, ver Joseph (1990) e as respostas publicadas em número subseqüente da mesma revista (Slatta, 1991; Singelmann, 1991; Birkbeck, 1991; Joseph, 1991).

5 Quanto ao aumento de furtos, raptos, extorsões, trapaças e fraudes, Scalise observou que, na província de Catanzaro, isso se deveu aos danos causados pela filoxera, uma praga que destruiu as riquíssimas vinhas dos habitantes de Nicastro, um dos municípios mais importantes da província. Também entre 1896 e 1899, em muitas aldeias do norte de Catanzaro, a mosca oleácea anulou por vários anos o produto das oliveiras.

6 Estamos supondo aqui que todos fossem calabreses. Temos informação sobre a naturalidade de 28 , e todos esses eram calabreses, o que sugere que os outros dez também o eram.

7 Fundação Pró-Memória de São Carlos, Processos Criminais, caixa 213, n. 243, Salvador Spadari, 1896.

8 Fundação Pró-Memória de São Carlos, Processo Mangano, declaração de Antonio Monteleone.

9 Fundação Pró-Memória de São Carlos, Processo Mangano, depoimento de Francesco Lascalla.

10 Fundação Pró-Memória de São Carlos, Processo Mangano, declaração de Antonio Farina.

11 Fundação Pró-Memória de São Carlos, Processo Mangano, declaração de Francisco Farina.

12 Fundação Pró-Memória de São Carlos, Processo Mangano, declaração de Antonio Monteleone.

13 Fundação Pró-Memória de São Carlos, Processo Mangano, declaração de Ernesto Falcone.

14 Fundação Pró-Memória de São Carlos, Processo Mangano, depoimento de Felix Martins Corrêa. 
15 Fundação Pró-Memória de São Carlos, Processo Mangano, depoimento de Angela Romana. A Opinião, 23/7/1898.

16 Fundação Pró-Memória de São Carlos, Processo Mangano, declaração de Francisco Lorijo.

17 Fundação Pró-Memória de São Carlos, Processo Mangano, declaração de Antonio Calsone.

18 Fundação Pró-Memória de São Carlos, Processo Mangano, declaração de Antonio Monteleone.

19 Expressão que designa tomar bebida alcoólica.

20 Fundação Pró-Memória de São Carlos, Processo Mangano, declaração de Antonio Calsone (grifo nosso).

21 Fundação Pró-Memória de São Carlos, Processo Mangano, declaração de Francisco Lorijo.

22 Fundação Pró-Memória de São Carlos, Processo Mangano, depoimento de Rafael Lagrutencia.

23 Fundação Pró-Memória de São Carlos, Processo Mangano, declaração de Achilo Aielo.

24 A tendência de culpar imigrantes pelo aumento da criminalidade manifesta-se em muitos países e em diversos momentos históricos (Tonry, 1997).

25 Fundação Pró-Memória de São Carlos, Processos Criminais, caixa 333, n. 2242 (1895); caixa 333, n. 1207/3644 (1897).

26 Bento Bueno, chefe de polícia, ao delegado de polícia de São Carlos, São Paulo, 24 de abril de 1896, Fundação Pró-Memória de São Carlos, Processos Criminais, caixa 334, n. 2235 (1896).

27 Arquivo do Estado de São Paulo, Polícia, várias latas.

28 Fundação Pró-Memória de São Carlos, Processos Criminais, caixa 279, n. 3719 (1895).

29 Fundação Pró-Memória de São Carlos, Processos Criminais, caixa 194, n. 105 (1889), Giuseppe Nancci Pizzuco, depoimento de Luiz Barbosa Corrêa.

30 Fundação Pró-Memória de São Carlos, Processos Criminais, caixa 462, s./n. (1894). Este conflito é discutido com mais detalhe em Monsma, 2000.

31 Segundo um oficial da Guarda Nacional, o nome (ou sobrenome) verdadeiro de Del Simoni era Fenaccio (depoimento de Augusto Souza Franco).

32 Depoimento de José Florêncio de Albertim Duarte.

33 Delegado de São Carlos a chefe de polícia (telegrama), 5/5/1896, Arquivo do Estado de São Paulo, C02832, Polícia; Rodolpho Faria a chefe de polícia, 2/5/1897, Arquivo do Estado de São Paulo, C02844, Polícia; Rodolpho Faria a chefe de polícia (telegra- ma), 30/4/1897, Arquivo do Estado de São Paulo, C02847, Polícia; Delegado de São Carlos a chefe de polícia (telegramas), 30/4/1897 e 4/5/1897, Arquivo do Estado de São Paulo, C02849, Polícia.

34 Sampaio sobreviveu.

35 Ludovico Gioia (cônsul d'Itália) ao chefe de polícia, 4/12/1897, Arquivo do Estado de São Paulo, C02839, Polícia.

36 Fundação Pró-Memória de São Carlos, Processos Criminais, caixa 333, s./n., 1897, depoimento de Antônio de Almeida Souza.

37 Fundação Pró-Memória de São Carlos, Processo Mangano, depoimento de Raphael Lagrutencia

38 Fundação Pró-Memória de São Carlos, Processos Criminais, caixa 213, n. 1195, depoimento de Domenico Lipero.

39 Fundação Pró-Memória de São Carlos, Processo Mangano, depoimento de Giuseppe Averse.

40 Fundação Pró-Memória de São Carlos, Processos Criminais, caixa 213, n. 1195, depoimento de Domenico Lipero.

41 Fundação Pró-Memória de São Carlos, Processo Mangano, depoimento de Rafael Lagrutencia.

42 Fundação Pró-Memória de São Carlos, Processo Mangano, declaração de Giuseppe Arcuri Giglioti.

43 Fundação Pró-Memória de São Carlos, Processo Mangano, declaração de Achillo Aielo.

44 Vários telegramas de Gaspar Berrance (delegado de São Carlos) a chefe de polícia, março de 1898. Arquivo do Estado de São Paulo, C02879, Polícia.

45 Fundação Pró-Memória de São Carlos, Processos Criminais, caixa 213, n. 213, 1908.

46 Gaspar Berrance a chefe de polícia (telegrama), 3/3/1898, Arquivo do Estado de São Paulo, C02887, Polícia; Gaspar Berrance a chefe de polícia, 3/4/1898 e 10/4/1898, Arquivo do Estado de São Paulo, C02884, Polícia.

47 Gaspar Berrance a chefe de polícia (telegrama), 18/4/1898, Arquivo do Estado de São Paulo, C02884, Polícia.

48 Gaspar Berrance a chefe de polícia (telegramas), 19/4/1898 e 21/4/1898, Arquivo do Estado de São Paulo, C02884, Polícia.

49 Fundação Pró-Memória de São Carlos, Processo Mangano, declaração de Ernesto Falcone.

50 3/4/1898, Arquivo do Estado de São Paulo, C02884, Polícia. 
51 Infelizmente, não temos informação sobre a origem regional da maior parte das vítimas e testemunhas italianas.

52 Aurelio Civatti a chefe de polícia, 30/8/1897, Arquivo do Estado de São Paulo, C02842, Polícia 1897.

\section{BIBLIOGRAFIA}

ABREU, Jonas Modesto de (2000), Política, economia e desenvolvimento urbano na cidade de São Carlos (1880-1960). Dissertação de mestrado, Universidade Federal de São Carlos.

ADORNI, Daniela. (1997), "Il brigantaggio", in Luciano Violante (org.), Storia d'Italia, annali 12, la criminalità, Torino, Einaudi.

ALVIM, Zuleika M. F. (1986), Brava gente! os italianos em São Paulo, 1870-1920. São Paulo, Brasiliense.

ANDERSON, Robert T. (1965), "From Mafia to Cosa Nostra". American Journal of Sociology, 71 (3): 302-310, nov.

BAILY, Samuel L. (1983), "The adjustment of Italian immigrants in Buenos Aires and New York, 1870-1914". American Historical Review, 88(2): 281-305, abr.

. (1999), Immigrants in the lands of promise: Italians in Buenos Aires and New York City, 1870 to 1914. Ithaca, Cornell University Press.

BANFIELD, Edward C. (1958), The moral basis of a backward society. Nova York, Free Press.

BIRKBECK, Christopher. (1991), "Latin American banditry as peasant resistance: a deadend trail?" Latin American Research Review, 26 (1): 156-160.

BLOK, Anton. (1974), The Mafia of a Sicilian village, 1860-1960: a study of violent peasant entrepreneurs. Prospect Heights, Illinois, Waveland Press. (2001a), "Social banditry reconsidered", in Anton Blok, Honour and violence, Cambridge, Polity Press.

. (2001b), "The blood symbolism of Mafia”, in Anton Blok, Honour and violence, Cambridge, Polity Press.

(2001c), "Explaining south Italian agro-towns", in Anton Blok, Honour and violence, Cambridge, Polity Press.

CONCEIÇÃO, Silvano da. (2001), O banditismo em São Carlos: o caso do bando Mangano (1894 a 1898). Monografia de conclusão de curso, Ciências Sociais, Universidade Federal de São Carlos.

DINNERSTEIN, Leonard \& REIMERS, David M. (1999), Ethnic Americans: a bistory of immigration. 4 ed., Nova York, Columbia University Press.

FAUSTO, Boris. (1984), Crime e cotidiano: a criminalidade em São Paulo (1880-1924). São Paulo, Brasiliense.

FOERSTER, Robert. (1919), The Italian emigration of our times. Cambridge, Cambridge University Press.

GAMBETTA, Diego. (1992), La mafia siciliana: un'industria della protezione privata. Torino, Einaudi.

HESS, Henner. (1998), Mafia e Mafiosi: origin, power and myth. Tradução de Ewald Osers, Nova York, New York University Press.

HOBSBAWM, Eric J. (1959), Primitive rebels. Manchester, Manchester University Press. . (2000 [1969]), Bandits. 4 ed., Nova York, The New Press.

JACOBSON, Matthew Frye. (1998), Whiteness of a different color: European immigrants and the alchemy of race. Cambridge, Mass., Harvard University Press.

JAMIESON, Alison. (1997), "Le organizzazioni mafiose", in Luciano Violante (org.), Storia d'Italia, Annali 12, La criminalità, Torino, Einaudi. 
JOSEPH, Gilbert M. (1990), "On the trail of Latin American bandits: a reexamination of peasant resistance". Latin American Research Review, 25 (3): 7-53.

(1991), "Resocializing' Latin American banditry: a reply". Latin American Research Review, 26 (1): 161-174.

JUNQUEIRA, Marili Peres. (1998), Nas entrelinhas dos jornais: cotidiano do imigrante italiano na imprensa de São Carlos (18801900). Dissertação de mestrado, Araraquara, Faculdade de Sociologia, Unesp.

KLEIN, Herbert S. (1989), "A integração dos imigrantes italianos no Brasil, na Argentina e Estados Unidos". Novos Estudos CEBRAP, 25: 95-117, out.

MONSMA, Karl. (2000), "Histórias de violência: processos criminais e conflitos interétnicos". Trabalho apresentado no XXIV Encontro Anual da Anpocs.

MONSMA, Karl \& MEDEIROS, Simone. (prelo), "Classe, etnia e violência nas fazendas de café do Oeste paulista, 1888-1914". Humanas (Universidade Federal do Rio Grande do Sul).

NELLI, Humbert S. (1970), The Italians in Chicago, 1880-1930: a study in ethnic mobility. Nova York, Oxford University Press. . (1976), The business of crime: Italians and syndicate crime in the United States. Chicago, University of Chicago Press.
POUTIGNAT, Philippe \& STREIFF-FENART, Jocelyne. (1997), Teorias da etnicidade. Tradução de Elcio Fernandes, São Paulo, Unesp.

SCALISE, Giuseppe. (1905), L'emigrazione dalla Calabria: saggio di economia sociale. Nápoles, Luigi Pierro.

SINGELMANN, Peter. (1991), "Establishing a trail in the labyrinth". Latin American Research Review, 26 (1): 152-155.

SLATTA, Richard W. (1991), "Bandits and rural social history: a comment on Joseph". $L a-$ tin American Research Review, 26 (1): 145-151.

TILLY, Charles. (1990), "Transplanted networks", in Virginia Yans-McLaughlin (org.), Immigration reconsidered: history, sociology, and politics, Nova York, Oxford University Press.

TONRY, Michael (org.). (1997), Ethnicity, crime, and immigration: comparative and cross-national perspectives. Chicago, University of Chicago Press.

TRENTO, Angelo. (1989), Do outro lado do Atlântico: um século de imigração italiana no Brasil. São Paulo, Nobel.

TRUZZI, Oswaldo. (2000), Café e Indústria: São Carlos, 1850-1950. 2 ed., São Carlos, Edufscar. 


\section{SOLIDARIEDADE ÉTNICA, PODER LOCAL E CRIME ORGANIZADO: UMA QUADRILHA DE BANDIDOS CALABRESES NO OESTE PAULISTA, 1895-1898.}

Karl Monsma, Oswaldo Truzzi e Silvano da Conceição

Palavras-chave

Bandidos; Crime organizado; Imigração; Italianos; Calábria.

A história de uma quadrilha de bandidos calabreses no município de São Carlos, oeste paulista, ao final do século XIX permitiu-nos investigar por que o banditismo italiano era raro no Brasil. A quadrilha contou com certa rede de apoio entre calabreses e com o silêncio de outros italianos, seja pela intimidação, seja pela desconfiança que estes nutriam das autoridades brasileiras. Uma epidemia devastadora de febre amarela, que afastou da região grande parte da elite local e debilitou a polícia, garantiu ao bando alguns anos de impunidade. $O$ fato de terem imigrado para a região italianos de várias origens não é suficiente para explicar a raridade do banditismo e do crime organizado entre italianos no Brasil. Dois fatores foram decisivos nesse sentido, ao contrário do que ocorreu na Calábria e nos Estados Unidos: ausência de elites dispostas a proteger bandidos imigrantes e dificuldade para os bandidos corromperem as autoridades locais, especialmente a polícia.

\section{ETHNIC SOLIDARITY, LOCAL POWER, AND ORGANIZED CRIME: A CALABRIAN GANG IN THE WEST OF SAO PAULO STATE, 1895-1898}

Karl Monsma, Oswaldo Truzzi and Silvano da Conceição

\section{Key words}

Bandits; Organized crime; Immigration; Italians; Calabria.

The story of a late $19^{\text {th }}$ century Calabrian bandit gang in the municipality of São Carlos, in western São Paulo state, allows us to investigate why Italian banditry was rare in Brazil. The bandits depended on a support network among Calabrians, and imposed silence on other Italians by either intimidation or distrust on Brazilian authorities. A devastating yellow fever epidemic, which drove away much of the local elite and seriously weakened the police force, helped the gang to enjoy a few years of impunity. The mixture of immigrant Italians from various regional origins is insufficient to explain the relative absence of banditry and organized crime among Italians in Brazil. Two issues were decisive to do so then, on the contrary of what happened in Calabria and the United States: the lack of Brazilian elites willing to protect immigrant bandits and the difficulty in corrupting local authorities, especially the police.

\section{SOLIDARITÉ ETHNIQUE, POUVOIR LOCAL ET CRIME ORGANISÉ: UN GROUPE DE BANDITS CALABRAIS À L'OUEST DE L'ÉTAT DE SÃO PAULO, 1895-1898}

Karl Monsma, Oswaldo Truzzi et Silvano da Conceição

\section{Mots-clés}

Bandits; Crime organisé; Immigration; Italiens; Calabre.

L'histoire d'un groupe de bandits calabrais à la ville de São Carlos, à l'ouest de l'État de São Paulo, à la fin du XIX $^{\mathrm{e}}$ siècle, nous permet de rechercher les raisons par lesquelles le banditisme italien était un phénomène si rare au Brésil. Le groupe a compté avec le soutien d'un réseau d'immigrants calabrais et avec le silence d'autres italiens, grâce à l'intimidation, ou à la méfiance des immigrants par rapport aux autorités brésiliennes. Une épidémie dévastatrice de fièvre jaune, qui a éloigné une bonne partie de l'élite locale et a affaibli la police, a garanti à ce groupe quelques années d'impunité L'hétérogénéité régionale des Italiens ne suffit pas pour expliquer la rareté du banditisme et du crime organisé parmi les Italiens au Brésil. L'histoire de ce groupe, outre la comparaison avec la Calabre et les États-Unis, indique l'importance décisive de deux facteurs : l'absence d'élites disposées à protéger les délinquants immigrants et les difficultés de ceuxci à corrompre les autorités locales, en particulier la police. 